\title{
Lessons Learned through Research Partnership and Capacity Enhancement in Inuit Nunangat
}

\author{
Natalie Ann Carter, ${ }^{1,2}$ Jackie Dawson, ${ }^{1}$ Natasha Simonee, ${ }^{3}$ Shirley Tagalik ${ }^{4}$ and Gita Ljubicic ${ }^{5}$
}

(Received 17 January 2019; accepted in revised form 19 August 2019)

\begin{abstract}
Facilitating research and enhancing community research capacity through a partnered approach in Inuit Nunangat (the Inuit homeland of Canada, located in Arctic Canada) presents learning opportunities and challenges for southern-based, non-Inuit researchers and community members alike. This article outlines lessons learned through the Arctic Corridors and Northern Voices (AC-NV) project, which involved 14 communities across Inuit Nunangat. The AC-NV focused on understanding community-identified impacts and potential management options of increased shipping in Inuit Nunangat due to sea ice reductions and a changing climate. The approach used to conduct the research involved visiting researchers and community partners working together with local organizations, and training and hiring northern youth as cultural liaisons and workshop co-facilitators. We strove to develop a model of collaborative partnership and strong north-south research relationships. In this paper, we draw on our broad learning experiences from four community case studies conducted as part of the AC-NV project: Arviat, Cambridge Bay, Gjoa Haven, and Pond Inlet, Nunavut. Close partnerships were formed in each of these communities, and 32 youth were trained in participatory mapping and workshop facilitation. For our diverse team of Inuit, northern- (i.e., non-Inuit, living in Inuit Nunangat), and southern-based non-Inuit researchers, our efforts to engage in partnered research were a critical component of the research and learning experience. In this article we share methodological reflections and lessons learned from what collaborative-partnered research means in practice. In so doing, we aim to contribute to the increasing dialogue and efforts around knowledge co-production and Inuit self-determination in research. Key conclusions of this reflective exercise include the importance of 1) conducting research that is relevant to local needs and interests, 2) visiting researchers and local organizations partnering together, 3) co-creating and refining knowledge documentation tools, 4) including youth cultural liaisons as co-facilitators, 5) conducting results validation and sharing exercises, and 6) being open to forming personal friendships. For the AC-NV, this community-based partnership approach resulted in more robust research results, strengthened north-south relations, and enhanced local capacity for community-led projects.
\end{abstract}

Key words: community-based research; Arctic; Inuit; youth; shipping; Inuit knowledge; enhancing capacity; north-south research relations; self-determination; partnership approach; methodology

RÉSUMÉ. Le fait de faciliter la recherche et de rehausser la capacité de recherche communautaire par le biais d'une démarche axée sur les partenariats dans l'Inuit Nunangat (la patrie des Inuits du Canada, dans l'Arctique canadien) présente des occasions d'apprentissage et des défis pour les chercheurs non inuits du Sud et les membres de la communauté. Cet article fait ressortir les leçons apprises grâce au projet « Arctic Corridors and Northern Voices (AC-NV) » ayant fait appel à 14 collectivités de l'Inuit Nunangat. Le projet AC-NV avait pour but de comprendre les incidences cernées par la communauté et les options de gestion éventuelles en matière d'intensification du transport des marchandises dans l'Inuit Nunangat en raison de l'amenuisement de la glace de mer et du changement climatique. La démarche de recherche s'est traduite par un travail mené en collaboration par des chercheurs invités, des partenaires communautaires et des organisations locales, de même que par la formation et l'embauche de jeunes du Nord à titre de liaisons culturelles et de coanimateurs d'ateliers. Nous nous sommes efforcés de concevoir un modèle de partenariat coopératif caractérisé par de solides relations de recherche entre le Nord et le Sud. Dans cet article, nous nous appuyons sur nos vastes expériences d'apprentissage découlant de quatre études de cas communautaires réalisées dans le cadre du projet AC-NV : Arviat, Cambridge Bay, Gjoa Haven et Pond Inlet, au Nunavut. Dans chacune de ces collectivités, des partenariats étroits ont été créés, et 32 jeunes ont été formés en cartographie participative et en animation d'ateliers. Grâce à notre équipe variée composée d'Inuits, de chercheurs du Nord (c'est-à-dire des chercheurs non inuits, mais qui vivent dans l'Inuit Nunangat) et de chercheurs non inuits du Sud, nos efforts de recherche en partenariat ont représenté une composante critique de l'expérience de recherche et d'apprentissage. Dans cet article, nous faisons part de nos réflexions méthodologiques et des leçons que nous avons tirées de la signification pratique de la recherche coopérative en partenariat. Ce

\footnotetext{
${ }^{1}$ Department of Geography, Environment and Geomatics, University of Ottawa, Ottawa, Ontario K1N 6N5, Canada

${ }^{2}$ Corresponding author: ncarte3@uottawa.ca

${ }^{3}$ PO Box 23, Pond Inlet, Nunavut X0A 0S0, Canada

${ }^{4}$ Aqqiumavvik Society, PO Box 44, Arviat, Nunavut X0C 0E0, Canada

${ }^{5}$ School of Geography and Earth Sciences, McMaster University, 1280 Main Street W, Hamilton, Ontario L8S 4K1, Canada

(C) The Arctic Institute of North America
} 
faisant, nous voulons faire notre part dans le dialogue de plus en plus prépondérant et dans les efforts relatifs à la coproduction de connaissances et à l'autodétermination des Inuits en matière de recherche. Parmi les grandes conclusions de cet exercice de réflexion, notons l'importance 1) de faire des recherches qui se rapportent aux besoins et aux intérêts locaux, 2) de faire en sorte que les chercheurs invités et les organisations locales travaillent en collaboration, 3) de coproduire et de peaufiner des outils de documentation des connaissances, 4) d'inclure les jeunes à titre de liaisons culturelles et de coanimateurs, 5) de procéder à la validation des résultats et à des exercices de partage, et 6) d'être prêt à nouer des amitiés personnelles. Dans le cas du projet $\mathrm{ACNV}$, la méthode du partenariat communautaire a permis d'obtenir des résultats de recherche plus solides, de renforcer les relations nord-sud et de rehausser la capacité locale en vue de projets communautaires.

Mots clés : recherche communautaire; Arctique; Inuit; jeunes; transport de marchandises; connaissances des Inuits; rehaussement de la capacité; relations de recherche nord-sud; autodétermination; démarche de partenariat; méthodologie

Traduit pour la revue Arctic par Nicole Giguère.

\section{INTRODUCTION}

Inclusion of Indigenous rights holders' perspectives in decision-making structures across Canada has been clearly articulated in the reconciliation mandate of Canada's current federal government (Department of Justice Canada, 2018). Significant effort and steps are being taken toward reconciliation and shared leadership approaches with Indigenous peoples through the Truth and Reconciliation Commission of Canada (TRCC, 2015), the 2016 U.S.Canada Joint Statement on Climate, Energy, and Arctic Leadership (OPM, 2016a), the 2018 Recognition and Implementation of Rights Framework (OPM, 2018), and implementation of the 2018 Principles Respecting the Government of Canada's Relationships with Indigenous Peoples (Department of Justice Canada, 2018). In addition to this federal focus on reconciliation in Canada, there is a strong commitment among decision makers to evidencebased decision making and support for science and research to inform decisions (Advisory Panel for the Review of Federal Support for Fundamental Science, 2017). However, there remain a number of challenges when striving for a dual mandate of strong science and reconciliation.

Canada's national Inuit organization represents all Inuit in Canada and has expressed concerns that colonial approaches to research and science in Inuit Nunangat continue to endure today (ITK, 2018a). It has been suggested that research in Inuit Nunangat has served as a tool for colonialism; some proponents believe this legacy has continued despite efforts toward improving nation-tonation relations (ITK, 2018a). The relationship between the research community and Inuit is rife with historic examples of racism and exploitation, particularly in the area of health science (McGregor et al., 2010; TRCC, 2015; ITK, 2018a). "Early approaches to the conduct of research in Inuit Nunangat had cast Inuit as either objects of study or bystanders. This legacy has had a lasting impact on Inuit peoples and continues to be reflected in current approaches to research governance, funding, policies, and practices" (ITK, 2018a:4, 5).

Inuit Tapiriit Kanatami's (ITK) National Inuit Strategy on Research (NISR) identifies that research is often resourced, conducted, and governed in ways that limit
Inuit participation (ITK, 2018a). Based on historic federal investment in Arctic research, the biological and physical sciences have been prioritized and less attention has been given to Inuit research priorities. Inuit priorities include a stronger focus on social and health sciences (ITK, 2018a). Indigenous peoples, including Inuit, have rich, relevant knowledge and expertise, and yet their knowledge has been largely left out of scientific efforts in the past - particularly in the biological and physical sciences (Gearheard and Shirley, 2007; NGPRC, 2009; McGregor et al., 2010). Several other factors have been identified that inhibit the ability of Inuit to participate fully in research that directly affects their homeland. These include outdated policies, lack of respect and understanding of Indigenous research methodologies and knowledge systems, institutional barriers, lack of control over the research agenda, budget, and university requirements, limited research experience, and lack of training (Gearheard and Shirley, 2007; ITK and NRI, 2007; NGPRC, 2009; McGregor et al., 2010; ICC, 2013; Ogden and Thomas, 2013; Brunet et al., 2014; Healey and Tagak, 2014; Ferrazzi et al., 2018; ITK, 2018a; McGrath, 2018). Despite these limitations, Inuit have been engaged in supporting and leading research for many years (MacDonald and Wachowich, 2018), often with little acknowledgement of their contributions to particular projects or to Arctic science more broadly.

Over the past four to five decades, collaborative approaches to research have evolved along with Inuit efforts to finalize and implement land claims (Gearheard and Shirley, 2007; Tondu et al., 2014; ITK, 2018a). More recently, transitions from participatory to partnership research have been emphasized (Brunet et al., 2014), and Inuit, non-Inuit researchers, and research institutions have strived to develop models of co-leadership and knowledge co-production that create value for Inuit and their communities (e.g., see Gearheard et al., 2013; Bell et al., 2014; Healey and Tagak, 2014; Harper et al., 2015; Pearce et al., 2015; Wesche et al., 2016; Cunsolo and Hudson, 2018; Henri et al., 2018; Ljubicic et al., 2018; Loseto et al., 2018; McGrath, 2018; Tomaselli et al., 2018). Though they are happening in a fragmented fashion, these partnerships occur out of respect and good will between particular individuals (ITK, 2018a). To achieve 
Inuit self-determination in research there is a need for coordinated actions to improve research governance, resourcing, methods, and sharing processes (ITK, 2018a). The NISR "envisions research being utilized as a building block for strong public policies, programs, and initiatives that support optimal outcomes for Inuit..." (ITK, 2018a:3). The NISR identifies five priority areas deemed necessary to ensure more impactful and meaningful research for Inuit, including to 1) advance Inuit governance in research, 2) enhance the ethical conduct of research, 3) align funding with Inuit research priorities, 4) ensure Inuit access, ownership, and control over data and information, and 5) build capacity for Inuit Nunangat research (ITK, 2018a). Each of these priorities has associated objectives and calls for actions according to the implementation plan and timelines, which aim to enhance Inuit capacity to lead research and cultivate Inuit researchers in future generations (ITK, 2018a).

At the same time as the NISR is being adopted to refine strategic research initiatives and policies, scientists and Inuit leaders continue to position Canada as a global leader in Arctic research through national and international programs (e.g., ArcticNet, Polar Knowledge Canada). These important national focus areas can go hand-in-hand or act in opposition, depending on the approaches, attitudes, and intentions of individuals involved. Therefore, it is important to continually reflect on the challenges that exist in achieving Canada's goals related to science excellence in evidence-based decision making and reconciliation.

This paper is a reflection and evaluation of the research process undertaken in the Arctic Corridors and Northern Voices (AC-NV) project, involving 14 communities across Inuit Nunangat. The goal of the AC-NV project was to understand community-identified impacts and potential management options of increased shipping in Inuit Nunangat due to sea ice reductions and a changing climate (see Carter et al., 2017a, b, 2018a, b; ESPG, 2019). The approach used to conduct the research involved visiting researchers and community partners working together with local organizations, and training and hiring northern youth as cultural liaisons and workshop co-facilitators. The AC-NV project was not only community based, it had the goal of facilitating research through a partnership approach and enhancing community research capacity.

Inuit Nunangat is a diverse region, jurisdictionally and culturally. While we draw on our broad learning experiences from working with the 14 communities, in this paper we focus specifically on our experiences in the four Nunavut communities of Arviat (Kivalliq Region), Cambridge Bay and Gjoa Haven (Kitikmeot Region), and Pond Inlet (Qikiqtaaluk Region) (Fig. 1). We endeavored to develop a model of co-leadership and strong northsouth research relationships. For our diverse team of Inuit, northern- (i.e., non-Inuit living in Inuit Nunangat), and southern-based non-Inuit researchers, our efforts to engage in partnered research were a critical component of the research and learning experience. In this article we describe what this co-leadership model means in practice, and we share our methodological reflections and lessons learned from working together. In so doing, we aim to contribute to the increasing dialogue and efforts around knowledge co-production and Inuit self-determination in research. For the AC-NV project, this community-based partnership approach resulted in more robust research results, strengthened north-south relations, and enhanced local capacity for community-led projects. On a broader scale, however, this work is part of the ongoing transition in how research is conducted in Inuit Nunangat.

\section{REGIONAL BACKGROUND}

Nunavut (Fig. 1) encompasses almost 2 million $\mathrm{km}^{2}$ of land and has the longest shoreline of any Canadian territory or province (GN, 2012; Statistics Canada, 2016). All but one of Nunavut's 25 communities are coastal. There are no roads into or out of the territory or between communities and there is limited marine infrastructure (GN, 2012). Nunavut residents depend entirely on aircraft and marine vessels to supply petroleum products and all goods and equipment needed for everyday living (GN, 2012). These products are shipped on marine vessels to communities annually and stored for use throughout the year (GN, 2012). Nearly half (46.3\%) of the total Inuit population in Canada reside in Nunavut, where $83.7 \%$ of the population identify as Inuk (singular form of Inuit), as compared to $0.18 \%$ nationally (Statistics Canada, 2016).

Arviat, Cambridge Bay, Gjoa Haven and Pond Inlet are coastal communities that maintain strong ties with traditional Inuit practices (Carter et al., 2017a, b; 2018a, b). Abundant in marine and terrestrial animals, the ecologically and biologically significant areas (DFO, 2011) surrounding these communities are essential travel, hunting, and harvesting grounds, and also provide sources of income for community members (Lee and Wenzel, 2004; Tyrrell, 2007; Kendrick and Manseau, 2008; Stewart et al., 2011; Beaumier et al., 2015; Karetak et al., 2017; Ljubicic et al., 2018; Tomaselli et al., 2018).

Community members depend upon the sea ice and marine ecosystem for sustenance and livelihoods, similar to many other Nunavut communities (Aporta, 2009; Laidler et al., 2009; Krupnik et al., 2010; Gearheard et al., 2013). Marine wildlife are important sources of skins, furs, and traditional or "country" food that "...contribute to the health and resilience of local social-ecological systems" (Tomaselli et al., 2018:2). Community members are on the land on a year-round, daily basis - where water, ice, land, wildlife, and Inuit themselves comprise the Inuit ecosystem. Being on the land and having access to country foods are fundamental to community members' nutritional health, mental and physical well-being, ways of life, and sense of place and identity (Bennett and Rowley, 2004; Cunsolo Willox et al., 2012; Durkalec et al., 2015; Karetak et al., 2017). Arctic sea ice and water are travel 


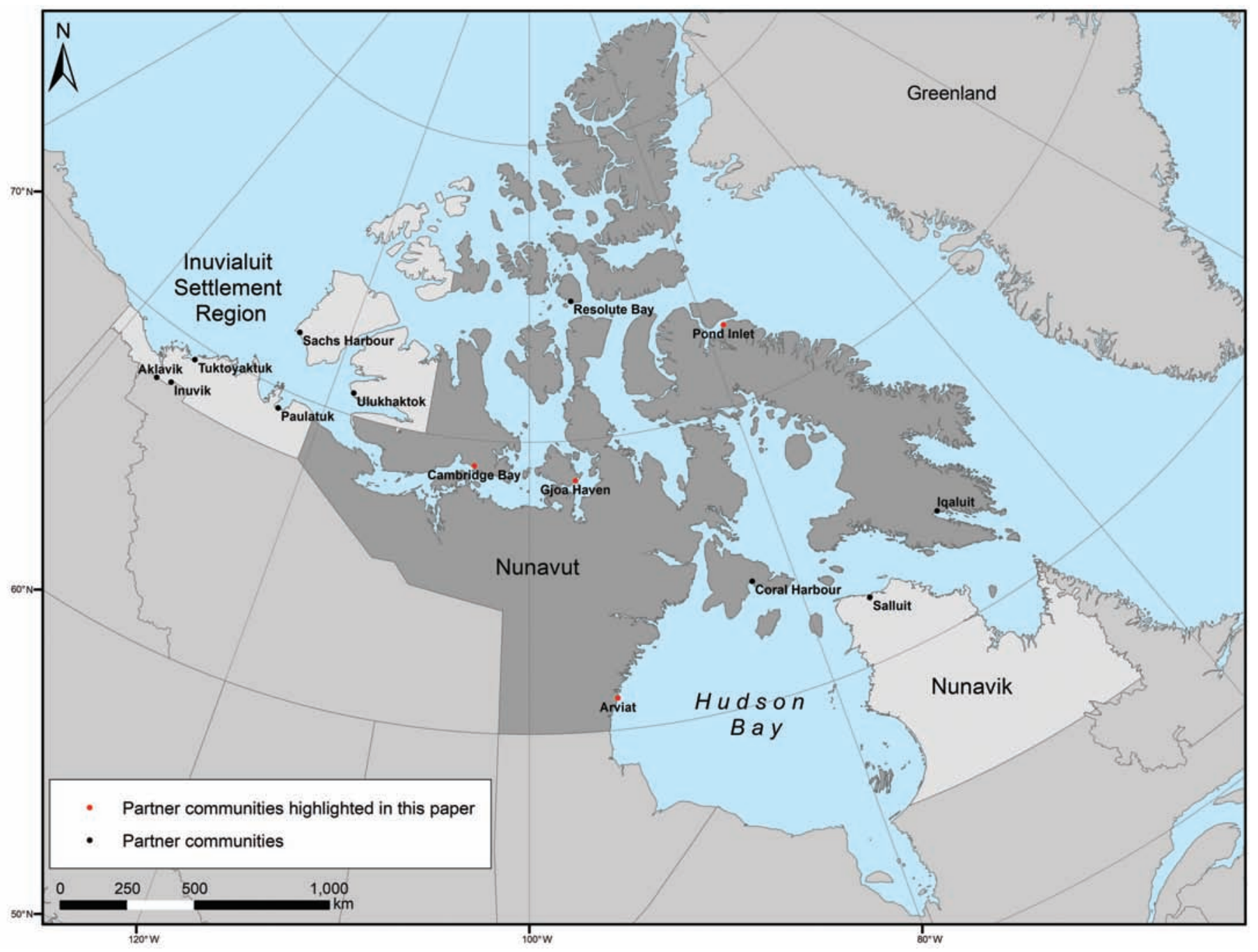

FIG. 1. Map of Nunavut and Arctic Corridors and Northern Voices research project partner communities.

routes, harvesting grounds, supporting networks that connect neighboring communities, and also play a critical role in the recreational and cultural values of local communities (ICC, 2008; Aporta, 2009; Gearheard et al., 2013). Of concern to the four partner communities in Nunavut, however, is that the marine areas identified as being most significant to community members for subsistence harvesting and livelihood activities are also the areas experiencing relatively rapid and recent increases in ship traffic (Pew Charitable Trusts, 2016; Carter et al., 2017a, b; 2018a, b; Chénier et al., 2017; Dawson et al., 2018, in press; ESPG, 2019) (Table 1).

\section{THE AC-NV BACKGROUND}

In response to observed and potential increases in Arctic marine shipping activity in Canada, the federal government has developed a network of Low-Impact Shipping Corridors (LISC) that encourage marine vessels to use identified routes that pose less risk and minimize impacts (OPM, 2016a, b; Chénier et al., 2017; Dawson et al., 2018). The LISC are also meant to provide a framework to guide future federal investments to support marine navigation safety in the North (Chénier et al., 2017), including improved charting and increased hydrography (OPM, 2016c). The LISC were developed using historical shipping data and an environmental risk framework, but did not initially include consideration of local concerns or knowledge from Inuit and northern residents.

Filling this important knowledge gap was the overarching aim of the AC-NV project, which involved two major activities: 1) creating a historical spatial shipping trends database for Arctic Canada (1990 to present) (see Pizzolato et al., 2014, 2016; Dawson et al., 2017, 2018), and 2) documenting Inuit knowledge of marine use areas and preferred ship routings to inform federal LISC implementation and management (Carter et al., 2017a, b, 2018a, b; Dawson et al., in press). Given the strong connections that Inuit communities have with the marine environment, their knowledge and understanding of local ecosystem dynamics are absolutely invaluable in effectively 


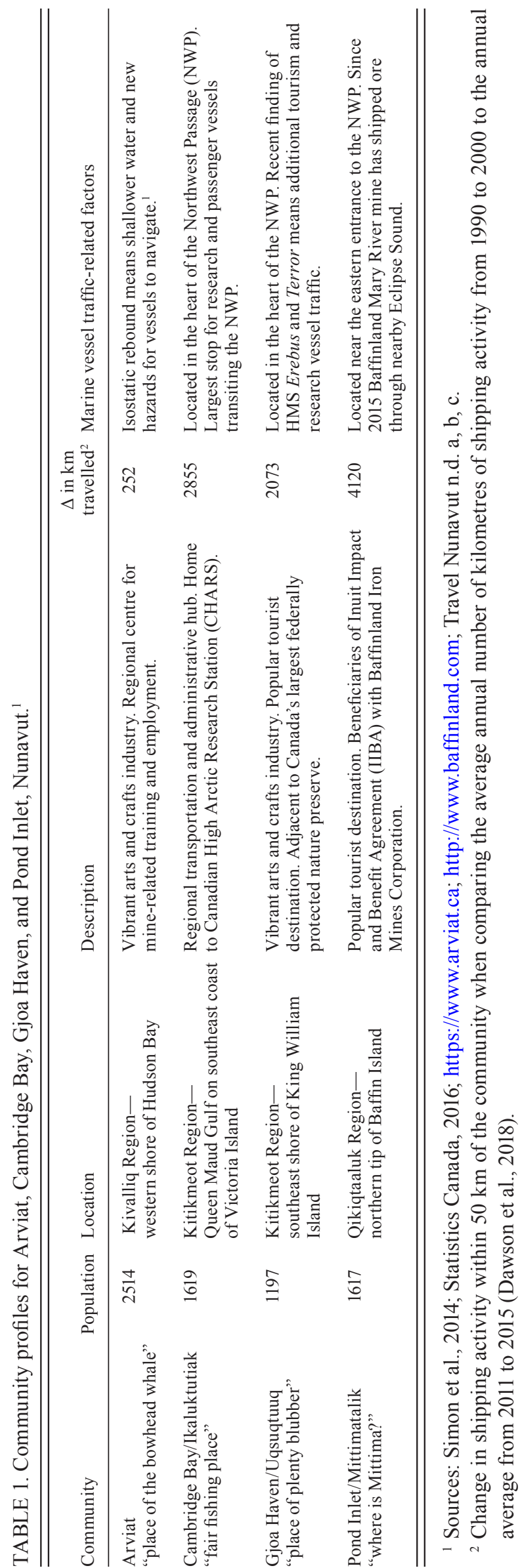

identifying significant marine areas that should be protected from shipping impacts. Furthermore, there is a moral and legal responsibility among decision makers to both work directly with and to fully consider local perspectives in the region's settled land claim areas (Government of Canada, 2011; ITK, 2018a). The results of activities in the AC-NV project will be shared in other publications. The focus of this paper remains on the methodology used and sharing what we learned from our experiences in engaging in partnership research and capacity enhancement in Nunavut.

\section{AUTHOR BACKGROUND}

Our authorship team reflects the diversity of the broader research team, including Inuk (N. Simonee), northernbased (S. Tagalik), and southern-based, non-Inuit researchers (N.A. Carter, J. Dawson, and G. Ljubicic). It is important to provide some context about our experiences and different roles in this project to reflect the perspectives presented in the paper. In the AC-NV project, N.A. Carter was a postdoctoral fellow and the community research lead. An experienced community-based researcher who had worked extensively in remote East African communities, Carter led the youth training and all community work with input and guidance from J. Dawson and G. Ljubicic. This project was her inaugural research project in Inuit Nunangat. J. Dawson has extensive community-based research experience in Inuit Nunangat, with 15 years of experience in developing, planning, and implementing community-based research related to Arctic tourism and shipping. At the time of project implementation, N. Simonee was the manager of the Mittimatalik Hunters and Trappers Organization (community partner) in Pond Inlet. She participated both as a youth cultural liaison, actively leading workshop co-facilitation in Pond Inlet, and as a research participant in this project. S. Tagalik is a retired educator living in Arviat. For the past 20 years she has worked closely with Inuit Elders to document their cultural knowledge, Qaujimajatuqangit (see Karetak et al., 2017), and she currently serves as a volunteer director for the Aqqiumavvik Arviat Wellness Society (community partner). In the AC-NV project she was actively involved in youth training, and as a note-taker and co-facilitator during the mapping and discussion workshops. G. Ljubicic has extensive cross-cultural, collaborative, research experience in Inuit Nunangat, with 17 years of experience in co-developing and implementing community-based research. Her work relates to topics such as sea ice, caribou, water, plants, and efforts to link Inuit and scientific knowledge in a complementary manner. Our reflections are drawn from a collective review of field notes, assessments of co-facilitated workshops, and informal discussions with youth, research participants, and among co-authors. Drawing on individual and collective experiences, this paper was written and refined collaboratively. Throughout the paper the term "we" is used to reflect our collective perspectives. We indicate experiences unique to community partners, youth cultural liaisons, or visiting researchers only when or as differentiation is required. 


\section{METHODS}

In the $\mathrm{AC}-\mathrm{NV}$ project, we employed a communitybased partnership approach. Our goal was to enhance local capacity to conduct vital (participatory) mapping and monitoring activities needed to inform ongoing federal shipping policy development and to enrich research quality and rigour (Ogden and Thomas, 2013; Healey and Tagak, 2014). Key project activities and dates of completion are presented in Table 2. Community-based research emphasizes "a robust level of community involvement that (ideally) leads to the coproduction of culturally respectful, relevant, and empowering knowledge" (Castleden et al., 2012:173). Community-based research adds credibility to studies by integrating community input, which can foster trust between the community and visiting researchers (Christopher et al., 2008). Community partners' participation in project development and implementation enhances community interactions and relationship building, collaborative effort, skills development, and training opportunities (Castleden et al., 2008). Participatory mapping, wherein maps are created by communities - often with the support of involved organizations - facilitates creation of "a valuable representation of what a community perceives as its place and the significant features within it... [both] natural physical features and socio-cultural features known by the community" (IFAD, 2009:4). Participatory mapping also affords community members opportunities to gain skills and expertise to conduct mapping independently, to document community members' spatial expertise, and to ensure that map ownership, as well as with whom and how to share mapped information, is determined by community members (IFAD, 2009).

The visiting researchers were invited by Pond Inlet community members and Ikaarvik Barriers to Bridges Program (Ikaarvik, 2015) to engage with them in the development and implementation of a research project investigating the impact of marine vessel traffic on marine areas and traditional activities (Dawson et al., 2016). Other researchers engaging with the Aqqiumavvik Society in Arviat and the Ekaluktutiak Hunters and Trappers Organization (EHTO) in Cambridge Bay informed the visiting researchers that marine vessel traffic had been identified as a priority there as well. When approached by the visiting researchers via introductory e-mails and follow-up phone calls, the Aqqiumavvik Society and EHTO readily agreed to work together to conduct the AC-NV project in their communities and became community partners.

Through research networks and existing relationships, visiting researchers partnered in each community with organizations known to engage in collaborative projects and facilitate workshops with the objective of building relationships that benefit local northern and visiting researchers (Table 2). The main community partners were as follows:
- In Arviat: The Aqqiumavvik Society, which runs the Young Hunters Program, gives youth opportunities to experience and learn traditional Inuit hunting practices and values (Prestwich, 2014), and to participate in a greenhouse initiative, in part as research assistants (Rogers, 2014).

- In Cambridge Bay: the EHTO manages fish and wildlife issues and actively educates youth and others about management of wildlife and ocean ecology (Shlag and Fast, 2005).

- In Gjoa Haven: the Junior Canadian Rangers Program offers youth opportunities to learn traditional and life skills while on patrol with Canadian Rangers.

- In Gjoa Haven and Pond Inlet: the Ikaarvik Barriers to Bridges Program aims to find meaningful ways of engaging local Inuit (especially youth) and northern communities in a joint effort with visiting researchers to better understand and respond to the impacts of climate change in remote regions.

In these four communities, a total of 32 Inuit and northern youth (approximately 15 to 30 years of age; 13 females and 19 males) were identified by community partners to participate in four of the community workshops that involved youth as co-facilitators (Table 2). Youth included current and recently graduated high school students who had expressed an interest in research, youth with research-work experience, delegates from the Hamlet Council and hunters' and trappers' organizations - who had expressed a professional interest in research, graduates of the Nunavut Arctic College Environmental Technology Program, and certified hunting guides. For youth who were minors, written parental consent was received in support of their participation. Many of the youth were active hunters or were active on the land through programs such as Young Hunters and Junior Canadian Rangers. Their level of research experience ranged from no prior experience to having been employed to conduct research in varying capacities with local organizations and researchers, and visiting researchers.

In each community, youth participated in a threeday-long, co-learning event that involved discussions of theoretical concepts and practical applications of qualitative research, participatory mapping, and focus group facilitation. Specific topics included in these events related to key questions and issues such as 1) why these visiting researchers and youth were selected to work together, and why we were gathered, 2) the definition of research, why research matters, who is and can be a researcher, qualitative versus quantitative research, connections between Inuit knowledge and scientific research, and participatory research (definition, methods), 3) the definition of shipping, why community involvement in discussions about shipping and low-impact shipping corridors is important, how to conduct community-based research about shipping, how to map culturally significant marine areas and management options to inform shipping activities and policy, 

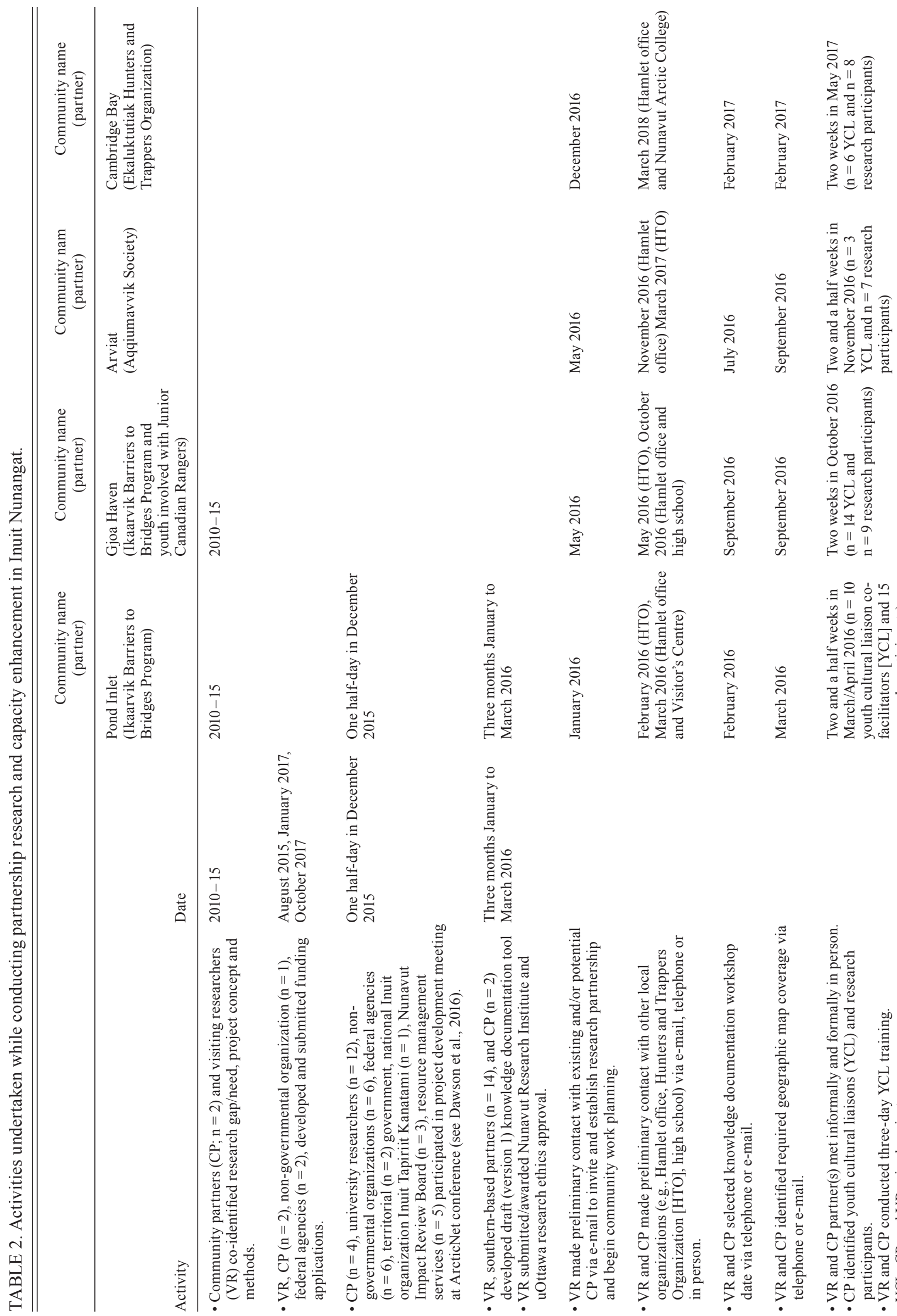

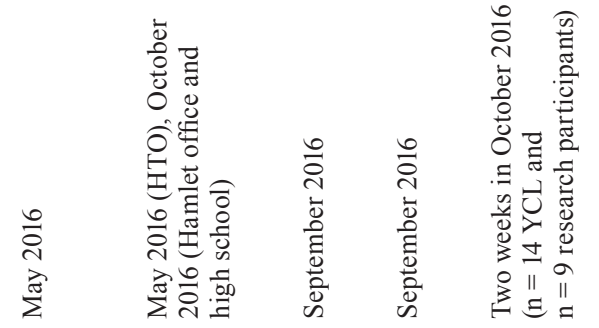
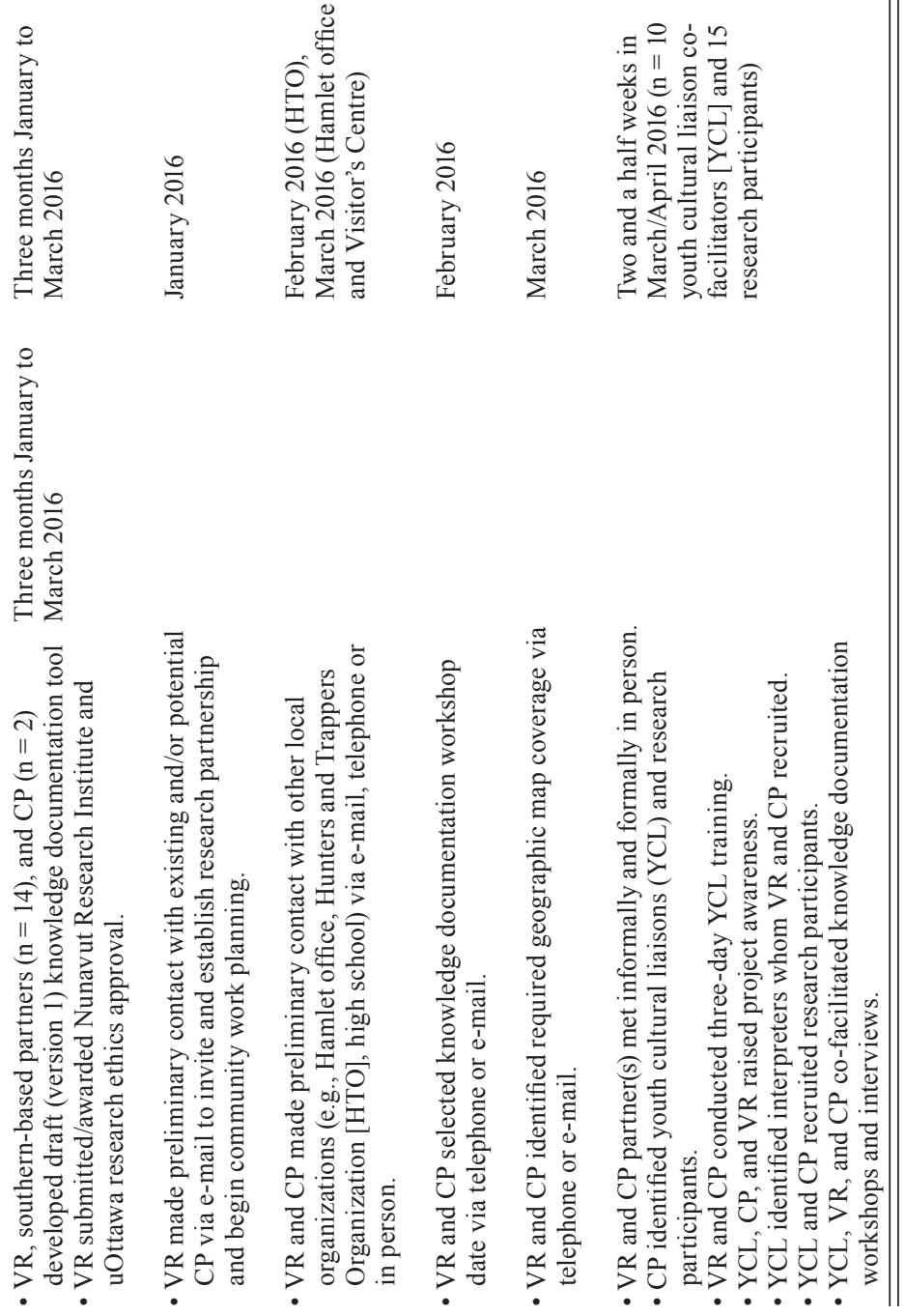


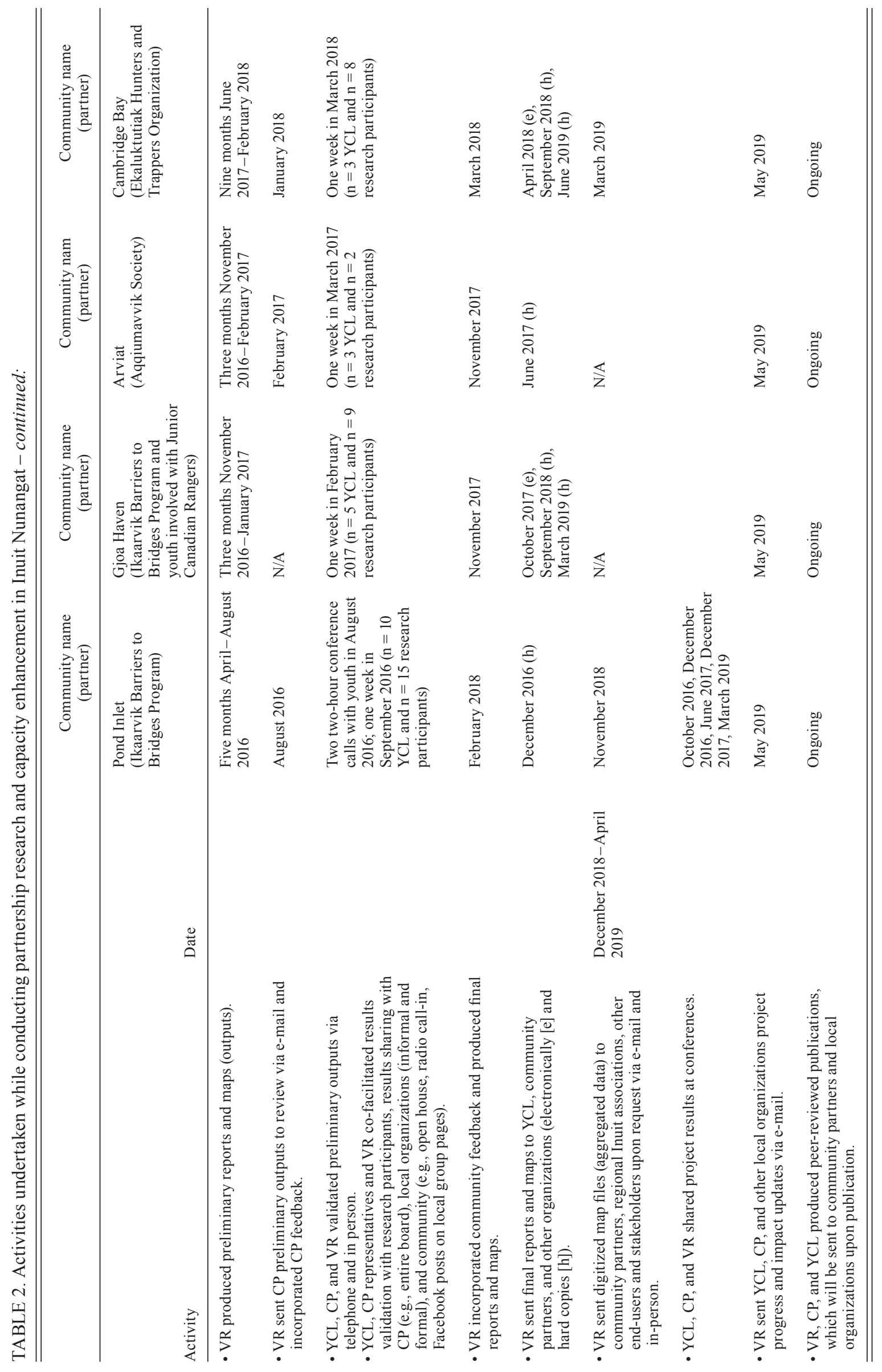


4) preparation for knowledge documentation, including: refining discussion questions (cultural nuances, probes, and forward- and back-translation), mapping methods and conventions (Tobias, 2009), note-taking, interpreter and research participant selection and recruitment, and raising community awareness about the project, 5) pre-test and further refinement of knowledge documentation tools, and selection of youth's (rotating) roles during knowledge documentation, and 6) knowledge documentation for the AC-NV project.

We initially overestimated the availability of youth and underestimated the amount of time required to conduct and complete the co-learning events. Flexible scheduling and frequent agenda modification were required. Thus, the visiting researchers planned for additional days spent in the community for co-learning, recruitment, knowledge documentation, and downtime. This had time and budgetary ramifications. As co-facilitators, visiting researchers supported youth by interjecting as needed. Visiting researchers also discussed inclusion criteria with community partners and youth, and modified as needed to ensure key research participants were invited. The visiting researchers invested in skilled, trained interpreters (as identified by community partners), who were keen to support youth and increase youth's comfort during co-facilitation, and avoided including only bilingual youth.

After these co-learning events, the youth were either hired or earned high school credit to immediately co-facilitate two days of knowledge documentation applying what they had learned about participatory mapping and focus groups (Table 2). Inuit knowledge and use of marine areas was documented via participatory mapping workshops (Table 2). These were supplemented by focus groups, interviews, formal and informal conversations, and results validation and sharing exercises. During the community mapping workshops, research participants shared their knowledge and experiences with us and each other; as such, we refer to this process as "knowledge documentation" rather than the more conventional scientific articulation "data collection." Co-facilitated by a visiting researcher and local youth, the knowledge documentation workshops were conducted with adult residents (ranging in age from mid-20s to 90s) in each community (Fig. 2). To ensure that participants were key knowledge holders and recognized as topical experts within the community, visiting researchers and local youth approached local organizations (e.g., hamlet offices, hunters' and trappers' organizations) whose members suggested potential research participants. These included a diversity of men and women, current and active users of local marine areas, holders of expert knowledge of significant sociocultural, archaeological, and ecological marine areas and travel routes, and those who would have knowledge of the potential impacts of marine vessel traffic. Local youth led the recruitment of participants through methods discussed with community partners and that were deemed most appropriate in their community (e.g., invitation letters,

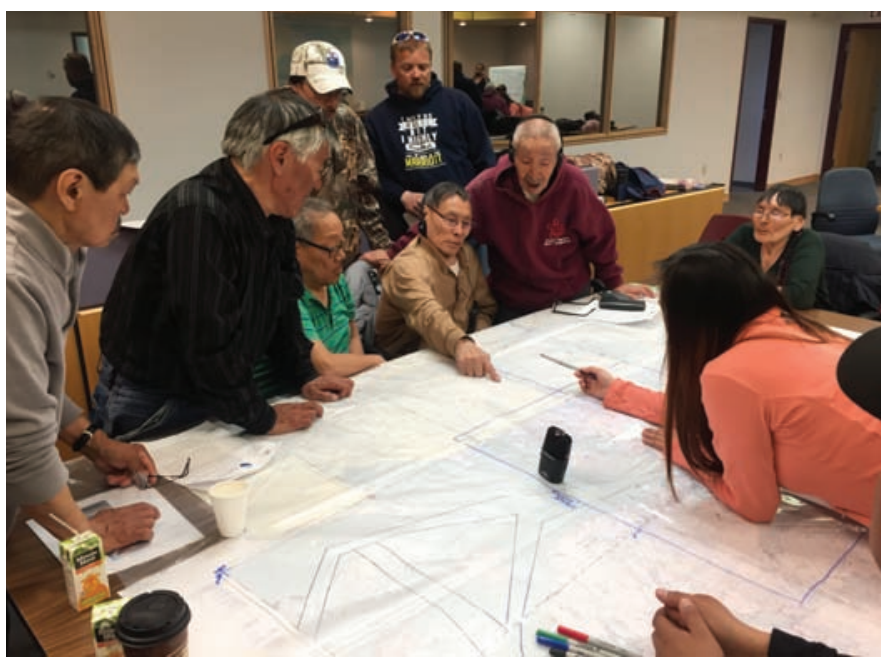

FIG. 2. Community members in Cambridge Bay, Nunavut, participating in a knowledge documentation workshop co-facilitated by local youth.

phone calls, and home visits). Research participants were not asked if they identified as Inuk. However, they articulated lifelong active engagement in local marine areas and most spoke Inuktut (the Inuit language). Discussions were conducted in English and Inuktut, simultaneously interpreted, and audio-recorded. Field notes were taken in English. Participants were remunerated for their time, as per local guidelines. During the workshops participants identified 1) wildlife habitat (e.g., feeding and breeding locations, migratory routes), 2) local harvesting and camping sites, 3) local travel routes, 4) potential impacts of marine vessel traffic, and 5) marine vessel-management options for the LISC specifically and local marine areas generally, for each season.

These areas were documented on topographic maps covered with plastic overlays using extra fine-tipped coloured markers, following conventions outlined in Tobias (2009).

Following knowledge documentation, a set of preliminary maps showing a compilation of participants' knowledge was produced (Table 2). Workshop transcripts were analysed using conventional content analysis (Nowell et al., 2017). For each community, a draft report summarizing the key findings was produced. These preliminary findings (community reports and maps) were validated during in-person meetings wherein the visiting researchers, youth, and community partners (hereafter "the research team") reviewed the findings together, then co-facilitated reviews in the community with available participants (ranging from hour-long individual reviews to hours-long group reviews; see Table 2). Results validation and sharing were conducted in person at research participants' requests, in ways that youth and research participants deemed most appropriate in their community (e.g., community meetings, Facebook posts); these differed by community. In each community, draft report summaries and maps were checked for accuracy and completeness first by youth co-facilitators, then by available research participants, then shared with community partners, 
organizations, and the broader community. Feedback was incorporated. The research team presented final results at a series of community meetings to gain broader feedback. Summary reports and maps were revised and included in final product outputs (see ESPG, 2019).

The benefits and challenges with conducting partnership research and capacity enhancement were jointly identified throughout the process of developing, facilitating, and verifying work done in the training and mapping workshops. These were documented in extensive field notes and through discussions amongst community partners, youth cultural liaisons, workshop co-facilitators, and visiting researchers. As a diverse author team representing the various roles within the research team, we have distilled our collective and individual reflections into six key lessons learned. In presenting these lessons, we incorporate specific examples from project activities, and we contextualize them according to the broader literature.

\section{RESULTS AND DISCUSSION}

\section{Lessons Learned}

Working together offered distinct research-related benefits and challenges, and in the process we learned many valuable lessons, including the importance of 1) conducting research that is relevant to local needs and interests, 2) visiting researchers and local organizations partnering together, 3) co-creation and refinement of knowledge documentation tools, 4) including youth cultural liaisons as co-facilitators, 5) conducting results validation and sharing exercises, and 6) being open to forming personal friendships.

\section{Conducting Relevant Research}

It is widely recognized that for research to be beneficial for Inuit communities and to spark meaningful community engagement, the research must be relevant to local needs and interests (Laidler, 2006; Gearheard and Shirley, 2007; ITK and NRI, 2007; Ogden and Thomas, 2013; MacDonald and Wachowich, 2018). Given their interest in increased vessel traffic, community members were more motivated to participate as partner organizations, youth co-facilitators, and research participants in the AC-NV project (Table 3). A high participation rate of expert knowledge holders (36 of 37 invited participants from all four communities attended), and participants' heightened engagement and desire to share knowledge and formulate management options resulted in an extensive depth and breadth of knowledge sharing. This included articulation of diverse, unambiguous perspectives, as well as rich context and detailed descriptions, and meticulous identification of spatial features and temporal aspects, all of which improved the overall quality of the research. A main challenge was that research participants displayed a sense of urgency for local feedback to be incorporated into policy and acted upon quickly (i.e., during the next shipping season), which was beyond the research team's level of influence. We learned that it was important to manage local expectations of timelines for results uptake into policy and action. Local expectations needed to be managed early on and throughout the project by reminding community members that the project was academic in nature and not a government consultation; that the results would be shared, but analysis is a time-consuming process; and that any changes to policy or behaviour were outside of the research team's control. A lack of research reporting has been a key factor in exploitative research relationships and lack of community trust in research in the past (Laidler, 2006; Gearheard and Shirley, 2007; ITK and NRI, 2007; ITK, 2018a), so it was important to discuss together and plan how to communicate results. We wanted to ensure that results were shared in diverse ways so as to maximize the potential for influencing decisions according to community goals - not just sharing within research venues (e.g., journal articles and conference presentations), but with community partners and decision makers as well. This required time and creativity, but it was important to consider different types of media and their effectiveness in reaching different audiences (ITK and NRI, 2007; Bonny and Berkes, 2008). Having these discussions early ensured research goals were relevant and beneficial to community partners.

\section{North-south Partnerships}

Community partners played a critical role in the success of the AC-NV project (Table 4). For instance, recognizing that the project was relevant to local needs and interests, community partners mobilized residents to participate. Community partners leveraged local networks and community ties to ensure key youth and knowledge holders were fully engaged. Community partners participated in co-learning, knowledge documentation, and results validation and sharing, and encouraged their members and the broader community to be involved in the project (Table 4). Also, community partners were well placed to mobilize youth who were 1) interested in research as evidenced through prior research involvement or an expression of interest, 2) engaged in the community, and 3) had knowledge (local and otherwise) that enabled them to help Northerners become comfortable with scientific research and to assist visiting researchers in learning about Inuit culture. Community partners supported fellow research team members and provided invaluable guidance and logistical support. The contribution of such partnerships to community mobilization and engagement, as well as the ease, efficiency, and quality of research, should not be underestimated. Engaging community partners in proposal and research design (Brunet et al., 2016) and considering their input and guidance into methods and mobilization of cultural advisors and research participants facilitated more successful, relevant, and meaningful research (Pearce et al., 2009; Brunet et al., 2016; Morris, 2016). 
TABLE 3. Benefits, challenges, and lessons learned from conducting partnership research and capacity enhancement that was relevant to local needs and interests in Inuit Nunangat.

\begin{tabular}{|c|c|c|}
\hline $\begin{array}{l}\text { - Participants' personal reflections prior to } \\
\text { knowledge documentation resulted in rich, } \\
\text { complex, clearly articulated views. } \\
\text { - Participants were engaged and shared detailed } \\
\text { knowledge extensively. }\end{array}$ & $\begin{array}{l}\text { - Community-specific foci were sub-themes of } \\
\text { the primary research focus. Ensuring that both } \\
\text { received due attention was challenging. }\end{array}$ & $\begin{array}{l}\text { - Plan time to ensure local needs and interests are } \\
\text { fully addressed. } \\
\text { - Opportunities for intergenerational knowledge } \\
\text { sharing are limited. Participants and youth value } \\
\text { these opportunities. }\end{array}$ \\
\hline
\end{tabular}

TABLE 4. Lessons learned while visiting researchers and local organizations partnered together to conduct research and capacity enhancement in Inuit Nunangat.

\begin{tabular}{|c|c|c|}
\hline Benefits & Challenges & Lessons learned \\
\hline $\begin{array}{l}\text { During project planning, implementation, and } \\
\text { results dissemination, community partners } \\
\text { (CP): } \\
\text { - Mobilized youth and research participants. } \\
\text { - Provided logistical support. } \\
\text { - Liaised between research team, local } \\
\text { organizations, and communities. } \\
\text { - Augmented youths' scope of knowledge. } \\
\text { - Mobilized communities to participate in results } \\
\text { sharing events. } \\
\text { - Shared results with their members. }\end{array}$ & $\begin{array}{l}\text { Existing workload strained CP's capacity to } \\
\text { communicate, participate, meet in person, review } \\
\text { results, and co-author papers. }\end{array}$ & $\begin{array}{l}\text { - Establish contact between visiting researchers } \\
\text { (VR) and CP prior to arrival in the community, } \\
\text { discuss potential timelines, and preferred modes } \\
\text { of contact. } \\
\text { - Expect and allow time for communication lags. } \\
\text { - Conduct formal and informal meetings between } \\
\text { VR, CPs, and local authorities. } \\
\text { - Respect CP's time and effort and heed local } \\
\text { remuneration guidelines. } \\
\text { - Ensure oral and written results reflect local } \\
\text { language and lexicon and consider local bandwidth } \\
\text { and printing limitations. } \\
\text { - Share results and maintain research relationships } \\
\text { post field work (e.g., provide journal publications } \\
\text { and project updates as applicable). } \\
\text { - Pay invoices promptly. }\end{array}$ \\
\hline
\end{tabular}

An important foundation for mutually respectful and beneficial research partnerships is engaging in early interactions and working together in research design and development, including 1) building or enhancing community-research relationships, 2) gaining community context, 3) engaging in collaborative research planning, 4) developing priorities for research questions, 5) identifying appropriate timelines, 6) assessing funding requirements, and 7) cultivating institutional support from community or research organizations (ITK and NRI, 2007; Pearce et al., 2009; Grimwood et al., 2012; Brunet et al., 2016; Ljubicic et al., 2018). Early interactions between visiting researchers and community partners were vital both for project success and to minimize local challenges or unintended disruptions. In the best-case scenarios, iterative, multiple, brief interactions (e.g., introductory e-mails, follow-up phone calls, in-person meetings in the community) occurred on a mutually agreed upon timeline before, during, and after community visits, making the process less onerous for all parties (e.g., discussing timing and logistics of knowledge documentation workshops during one phone call and identifying ideal map scale and geographic scope during another). Making appropriate base map decisions for (participatory) Indigenous land occupancy and marine resource mapping (e.g., topographic scale, geographic extent, north arrows, bar scales) enabled users to economically and accurately communicate information (Butler et al., 1987; IFAD, 2009; Tobias, 2009). A major challenge experienced by community partners was that existing workloads made it difficult to fully engage during all aspects of project development, implementation, and dissemination. Others report that funding, personnel, and availability can also restrict community partners' involvement (Pearce at al., 2009; Morris, 2016). Visiting researchers strove to be mindful of this by providing only brief updates, preparing key requests in advance of calls or meetings, and rescheduling as needed. Community partners identified the importance for visiting researchers to communicate with potential community partners months in advance of proposed community work through brief introductory e-mails followed by phone calls-ideally at the proposal development stage. Community partners advised that it would be helpful for visiting researchers to clearly articulate 1) the anticipated project scope and community involvement, 2) timelines, 3) what was unique, important, and relevant or beneficial to the community about the project, and 4) requests for local organization feedback and support for the project. If there was local support, then it was important to follow up according to suggestions about who would be a main point of contact or go-to person. 
Remuneration of community partners was done promptly and in accordance with local guidelines and standards, which varied from region to region and even among nearby communities.

\section{Tool Co-creation and Refinement}

Defining questions and deciding on appropriate methods are essential elements in a partnership approach to research (Pearce et al., 2009; Healey and Tagak, 2014; Beaumier et al., 2015; Brunet et al., 2016). Importantly, co-creation needed to be considered from the outset, in terms of identifying local priorities and planning the project, and also needed to be considered throughout all research phases (ITK and NRI, 2007; Brunet et al., 2014; Healey and Tagak, 2014; Ljubicic et al., 2018). This method goes beyond advisory capacity and engages community partners (and in our case youth cultural liaisons and co-facilitators) in developing the questions and workshop methods. Visiting researchers, southern-based project partners (e.g., non-governmental organizations, federal agencies), and community partners iteratively co-developed a draft semistructured discussion group guide via e-mail and in-person discussions. In the initial partner community, Pond Inlet, questions were read aloud one at a time and youth discussed the most concise, apt, culturally appropriate way to ask each question in English and Inuktut until consensus was reached. The visiting researchers and community partner interjected minimally during the translation and backtranslation processes doing so only to request clarification and verify final versions of each question. The refined questions served as the starting point in other communities. Across communities, the intent of the questions remained the same with only minor variations that reflected local dialect and phrasing.

The quality of interpreters and the effectiveness of translation between Inuktut and English was not only a practical means of facilitating communication and minimizing misunderstanding; it was a matter of interpreting between worldviews, communicating underlying meanings and concepts of nuanced forms of speech (in either language and including body language and gestures), and ultimately an exercise in crosscultural understanding (Laidler, 2006; Karetak et al., 2017; MacDonald and Wachowich, 2018). Simultaneous forward- and back-translation ensured original nuances and equivalence between both languages were maintained (Yu et al., 2004). This helped to validate the cultural relevance of the translation process (Wang et al., 2006). In every community, translating between English and Inuktut required wordsmithing. For instance, in Inuktut there is no single word for "season" and no equivalently nuanced word for "impact," which were both key concepts in the AC-NV project. Entire phrases were required to appropriately convey those meanings in the same way in both languages. Co-refinement of the knowledge documentation tool resulted in a culturally appropriate tool tailored to community perspectives (Table 5). This increased participant comprehension, thereby ameliorating the quality of the information shared and the overall quality of the research.

Through co-refinement, youth co-facilitators gained intimate knowledge and familiarity with the project topic, objectives, and the knowledge documentation tool. The opportunity to tailor the tool to reflect the interests and research priorities of their community contributed to youths' senses of pride and ownership in the research project, contributing positively to community and research participant engagement and research quality. For example, in Pond Inlet a passionate debate about potential interpreters occurred spontaneously between youth; the relative merits of potential candidates were highly contested during an in-depth discussion. A community partner later commented that at that moment she knew that the youth had taken ownership of the project and were debating so as to increase the likelihood of its success. The involvement of youth in research, in the development of research instruments and methods, and as cultural liaisons and advisors is an important factor in the success of research initiatives (Powers and Tiffany, 2006; Morris, 2016).

The main challenge was that knowledge documentation tool refinement and forward- and back-translation were tedious and time consuming. Attention to detail and nuance were critical in this iterative process; thus, it was important to plan sufficient time to engage in this process and not be rushed. The research team planned for frequent breaks and prepared concise questions. Visiting researchers hired interpreters to participate in this process.

Youth input was extremely valuable, but community partners advised that youth are not always recognized by the community as key knowledge holders for the research topic. Thus, any local knowledge that youth provided was validated by the research participants (e.g., descriptions of local seasons and identification of animals harvested locally). Community partners noted that local involvement would impact community perceptions of visiting researchers and the research project. Moreover, they suggested that it may be best to work directly with adults or Elders, depending on the topic, rather than have youth involved in every project. Community partners further stressed that visiting researchers should consult them about the feasibility and advisability of including youth, as well as the importance of asking for the identification and invitation of youth interested in research involvement. Community partners reported that communities wished to be involved in all levels and aspects of projects, not just for planning or permissions at the beginning. Often visiting researchers' budgets limit this level of participation or do not allow for meaningful collaboration. The benefit of community partners and visiting researchers jointly developing research funding proposals is that appropriate budget allocations and timelines can be determined at the outset, so that they are built into project planning. 
TABLE 5. Benefits, challenges, and lessons learned while co-refining a knowledge documentation tool with youth cultural liaisons (YCL) while conducting partnership research and capacity enhancement in Inuit Nunangat.

\begin{tabular}{|c|c|c|}
\hline $\begin{array}{l}\text { - YCL gained a deep understanding of project } \\
\text { objectives and potential benefits of community } \\
\text { involvement. } \\
\text { - YCL became project champions, raised community } \\
\text { awareness about the research topic, and fostered } \\
\text { trust between VR and the local community. } \\
\text { - Focused, appropriate, locally relevant questions } \\
\text { meant the research team was prepared and } \\
\text { respectful of participants' time. } \\
\text { - YCL involvement reduced experts' burden of } \\
\text { knowledge sharing. } \\
\text { - The depth, breadth, and overall quality of the } \\
\text { research was improved. }\end{array}$ & $\begin{array}{l}\text { - Tool refinement and forward- and back-translation } \\
\text { are tedious and time consuming. } \\
\text { - Attention to detail and nuance are critical. } \\
\text { - The process was tiring and difficult for YCL and } \\
\text { VR. }\end{array}$ & $\begin{array}{l}\text { - Develop concise draft research questions. } \\
\text { - Take frequent breaks to assist with maintaining } \\
\text { focus and quality during this process. } \\
\text { - Request input from a skilled interpreter. } \\
\text { - Nuanced questions are better understood when } \\
\text { phrased in the local lexicon and speech patterns. } \\
\text { - Co-refine knowledge documentation tools in an } \\
\text { effort to improve participants' research experience. }\end{array}$ \\
\hline $\begin{array}{l}\text { - Forward- and back-translation increased the } \\
\text { likelihood that original nuances were maintained } \\
\text { and homogeneous across languages. This } \\
\text { contributed to maintaining the primary research } \\
\text { focus, achieving stated objectives, and eliciting } \\
\text { pertinent, relevant knowledge (data). }\end{array}$ & $\begin{array}{l}\text { - Lengthy discussions between VR and YCL and } \\
\text { among YCL transpired when English and Inuktut } \\
\text { words misaligned (e.g., there is no Inuktut word } \\
\text { for "season" and no equivalently nuanced word for } \\
\text { "impact," thus descriptive phrases were required). }\end{array}$ & $\begin{array}{l}\text { - Conduct this iterative process in advance } \\
\text { of knowledge documentation so that these } \\
\text { discussions do not occur during knowledge } \\
\text { documentation (less time, less burden on research } \\
\text { team and participants). } \\
\text { - Plan time and budget for forward- and back- } \\
\text { translation. }\end{array}$ \\
\hline
\end{tabular}

\section{Youth Cultural Liaisons as Co-facilitators}

One of the biggest limitations, as identified in the literature of past research conducted in Inuit Nunangat by visiting researchers, is that the visiting scholars often lack cultural awareness and sensitivity-due in part to inexperience, lack of awareness of cultural protocols and language, and to varying degrees unacknowledged biases of scientific or colonial worldviews (Gearheard and Shirley, 2007; ITK and NRI, 2007; Healey and Tagak, 2014; Tondu et al., 2014; ITK, 2018a). To address this limitation, our research team worked with youth to understand community context, ethical practices according to Inuit cultural protocols, and approaches to effective communication. This meant not only that visiting researchers gained cultural awareness and context, but that youth took the leadership role in engaging with community members so that workshop facilitation was already tailored to the most relevant topics and language, and that people were more comfortable with the workshop interactions. Therefore, local youth played a critical role in project development, implementation, results validation, and sharing (Table 4). Youth provided rich cultural insight during refinement and back-translation of the draft knowledge documentation tool. They identified sensitive issues with potential to be perceived as intersecting with the research topic, enabling the research team to proactively maintain the primary research focus and thus achieve the stated objectives. For instance, in Pond Inlet, Baffinland Iron Mines Corporation had proposed an increase in the duration of the shipping season. Youth alerted the visiting researchers that the topic was contentious among community members. Thus, the research team prepared to listen and document mine vesselrelated concerns and then guide the conversation to include other shipping-related benefits, concerns, and management options.

Youth also identified key harvesting areas to inform map requirements. By identifying local seasons, wildlife, and harvesting activities, as well as potential probing questions, youth tailored the research to be community-specific. This enabled more focused discussions on the specific shipping issues of interest and enhanced the quality of the research. Youth map and question design input also enhanced the research participants' experience, as the workshop duration was reduced, and questions that were irrelevant, inappropriate, or had been asked previously or repeatedly during other research initiatives were avoided (Clark, 2008; Morris, 2016). Youth provided visiting researchers with context, thereby eliminating the need for research participants to answer context questions that were often repeated across research initiatives. Such preparatory work was also critical for visiting researchers to gain a fuller understanding of Inuit worldviews and to build long-term relationships in communities (Nadalin et al., 2013; Healey and Tagak, 2014).

The intimate involvement of youth in personalizing the knowledge documentation tool for their community created a sense of project co-ownership and a deep understanding of the research questions and objectives. Thus, in addition to being community members themselves, with existing social networks within the community, youth became project champions. Youth liaised between visiting researchers and the community, thus fostering trust and understanding. For instance, youth raised community awareness of the research topic at public events (e.g., flea market, community meetings) and via radio and Facebook groups; they talked about their own ongoing involvement and that of the research participants in the $\mathrm{AC}-\mathrm{NC}$ project. Youth also 
TABLE 6. Benefits, challenges, and lessons learned while including local youth cultural liaisons (YCL) as co-facilitators during partnership research and capacity enhancement in Inuit Nunangat.

\begin{tabular}{|c|c|c|}
\hline Benefits & Challenges & Lessons learned \\
\hline $\begin{array}{l}\text { - YCL provided cultural insight during project } \\
\text { planning, tool refinement, and implementation. } \\
\text { - YCL answered questions participants would } \\
\text { otherwise have been asked and thus reduced } \\
\text { research fatigue by shifting burden from research } \\
\text { participants } \\
\text { (e.g., youth pre-identified local seasons). }\end{array}$ & \multirow[t]{2}{*}{$\begin{array}{l}\text { - Strong community ties restricted YCL's } \\
\text { availability (family demands, school, jobs, } \\
\text { extracurricular activities). } \\
\text { - Participants' expectation of YCL local knowledge } \\
\text { inhibited provision of fully articulated responses. } \\
\text { - Cultural norms hampered YCL's comfort in } \\
\text { requesting further elucidation from Elders and } \\
\text { other research participants. }\end{array}$} & $\begin{array}{l}\text { - Discuss YCL availability, and adjust plans } \\
\text { accordingly. } \\
\text { - Be flexible, supportive, and use time wisely. } \\
\text { - Plan and budget for sufficient time. } \\
\text { - Remind research participants of the need for } \\
\text { context and clarity to ensure VR understand } \\
\text { context fully. } \\
\text { - Co-facilitate knowledge documentation workshops } \\
\text { to minimize YCL discomfort and avoid gaps in } \\
\text { knowledge documentation. }\end{array}$ \\
\hline $\begin{array}{l}\text { - YCL identified sensitive issues intersecting } \\
\text { with the research topic (e.g., proposed mine } \\
\text { expansion could result in year-round ship traffic) } \\
\text { and informed VR. This enabled the research } \\
\text { team to work proactively to maintain primary } \\
\text { research focus during knowledge documentation } \\
\text { workshops. }\end{array}$ & & $\begin{array}{l}\text { - Discuss sensitive issues, and research the issues as } \\
\text { needed. } \\
\text { - During knowledge documentation: 1) acknowledge } \\
\text { the intersecting issues and 2) compare and contrast } \\
\text { those issues with the research topic. } \\
\text { - Discuss participant inclusion criteria. } \\
\text { - Modify inclusion criteria accordingly. }\end{array}$ \\
\hline \multirow{2}{*}{$\begin{array}{l}\text { - YCL advised the VR that participant inclusion } \\
\text { criteria must be expanded to include Elders, per } \\
\text { cultural norms. } \\
\text { - Intergenerational knowledge sharing was valued } \\
\text { by research participants and YCL alike, enhanced } \\
\text { engagement, and ensured that knowledge was } \\
\text { not extracted for the sole benefit of visiting } \\
\text { researchers. } \\
\text { - Study validity was strengthened through inclusion } \\
\text { of Elders' extensive knowledge. } \\
\text { - Study validity was strengthened by Elders' } \\
\text { presence, which enabled recommendations } \\
\text { for corridors management options to be made, } \\
\text { per cultural protocol surrounding decision- } \\
\text { making. }\end{array}$} & $\begin{array}{l}\text { - Elders relayed knowledge and stories that VR } \\
\text { perceived as straying from the primary research } \\
\text { focus. This strained time limitations and required } \\
\text { skilled facilitator techniques to revert to intended } \\
\text { focus. }\end{array}$ & $\begin{array}{l}\text { - Discuss and follow cultural norms and } \\
\text { expectations. } \\
\text { - Plan time and budget for Elders to share } \\
\text { knowledge. }\end{array}$ \\
\hline & $\begin{array}{l}\text { - Knowledge documentation was conducted in the } \\
\text { local Inuktut dialect. } \\
\text { - YCL's degree of fluency affected the skill and } \\
\text { comfort with which they co-facilitated. } \\
\text { - Skilled interpreters were required. }\end{array}$ & $\begin{array}{l}\text { - Language and culture or one's sense of "Inukness" } \\
\text { are deeply connected. Maintain a high degree of } \\
\text { sensitivity to this. } \\
\text { - Involve bilingual youth when possible. } \\
\text { - Invest in a skilled, trained interpreter and hire two } \\
\text { if budget allows. }\end{array}$ \\
\hline
\end{tabular}

went on the local radio to dispel misunderstandings about the visiting research team and research topic. For instance, in Pond Inlet, youth learned that a local official had shared erroneous information about the AC-NV project and the visiting researchers' affiliation over local radio. Within one hour of learning of the misunderstanding, youth went on radio to correct and clarify project information. Youth also provided ongoing feedback throughout analyses, map digitization, and draft report preparation via phone, social media, in-person meetings, and manuscript preparation.

As mentioned previously, only one participant across the four Nunavut communities declined the invitation to participate, and none withdrew from the project. Nadalin et al. (2013) report that employing research methods that are culturally sensitive, as well as directly engaging and employing members of the community can improve participation rates. Research participants were highly engaged, and the extensive knowledge and perspectives they shared were rich, complex, and detailed. Community partners in several communities indicated that a key motivation for participants might also have been that youth would be learning from the knowledge they shared. Certainly our sense was that during the mapping exercises and discussions, community members were sharing knowledge with one another, including and importantly, with local youth. Elders wanted to share, and youth wanted to learn.

Visiting researchers tend to work with these two groups separately or act as facilitators to bring Elders and youth together for research purposes. In our case the visiting researchers supported youth to develop facilitation skills, which meant that youth worked with and learned from Elders directly. Thus, while involving both youth cultural liaisons and Elders was a good research practice that resulted in meaningful results, the visiting researchers were not the sole beneficiaries. Rather, this approach contributed to (re)connections between generations, between families that may not always be engaged with each other in the community, enhancing inter-personal relationships, and passing on knowledge that may be used and carried forward by youth (and community partners) in a way that could never be done by visiting researchers alone (MacDonald and Wachowich, 2018; McGrath, 2018). One youth in Cambridge Bay reflected, "Yes, it was good to work with community members and Elders to learn their knowledge."

Youth also played an important role in refining the inclusion criteria for inviting participants to AC-NV workshops. Initially, visiting researchers had considered focusing primarily on involving community members who are currently active on the land (i.e., those who may 
have observed recent impacts of shipping around their communities). Youth stressed the importance of including Elders and the merits of including Elders' knowledge and perspectives, even though they may no longer be active on the land. Youth advised that the lack of involvement by Elders could create a cultural disconnect, discomfort, and reluctance among research participants to confirm youth-identified descriptions of seasons, document culturally significant areas, and articulate shipping management options. Therefore, Elders were invited at the recommendation of youth. Elders' presence increased the validity of the study directly through inclusion of their extensive knowledge and observations of change over time. Their engagement also took the onus off younger research participants who were reluctant to articulate management options until Elders had spoken. Once Elders had spoken, some adult participants would articulate additional optional management options for discussion by the group. As others have reported, Elders are consulted in community decisionmaking processes, and are often tasked with making important decisions given their wealth of vital traditional knowledge (Qitsualik, 1999; Barnaby et al., 2009). In the ways that they conduct themselves and through their expectations for the community, Elders demonstrate leadership, foster the social and spiritual wellness of youth, and disseminate culture, language, and knowledge (Preston et al., 2015). However,

The prominent role Elders have in passing traditional knowledge is being undermined by language loss, the increasing prominence of southern influences in the north, and the erosion of traditional learning environments. Opportunities for elders to pass on skills associated with living on the land for instance, once an everyday feature of life, now occur much less frequently. Consequently, it is critical that efforts now be made to document this traditional knowledge and support new ways for elders to pass it on to youth.

(GN, 2010:2)

Indeed, youth co-facilitators, along with research participants, relished the opportunity to interact with Elders and learn through their storytelling. Youth reflected that they enjoyed learning about local marine use areas (past and present) and hearing Elders' stories and perspectives. Elders reflected that they enjoyed sharing their knowledge with younger generations and expressed pleasure that their knowledge was documented by younger community members. For instance, one Cambridge Bay Elder research participant said to the youth,

My children and my grandchildren if they ask the right people 'What did my grandfather do?' I like [knowing] that this is to be here. You know what you're doing is very important and don't stop here... What you did here with the Elders for the past couple of days it is very important. It is going to be documented one way or another and it's going to be there for a long time. And I am very fortunate to be here today with you and document the importance of the hunting areas and the camp areas; the location of where we get the fish. You're going to be able to say "Hey, I did this with the Elders." My kids are going to know about this and your kids are going to know about this. What you did for the past couple of days is very important.

Like Powers and Tiffany (2006:879), we found that including youth cultural liaisons as co-facilitators and engaging them in research not only generated "useful knowledge for communities and individuals" but also enabled opportunities for "the development and empowerment of youth participants, leading to benefits for young people...." Creating opportunities and empowering youth are important components of our lessons learned. The development of necessary skills and confidence to conduct research on their own, on topics of interest to them or those highlighted as priorities in their community, addresses multiple actions recommended in the NISR as outlined earlier (ITK, 2018a). Having youth co-facilitate the mapping and focus group discussions enhanced local capacity. For instance, Cambridge Bay youth reported new and improved facilitation and group work skills, as well as new mapping and note-taking skills. One of them noted that the experience would contribute to their credentials as a licensed hunting-guide. Knowledge documentation was an extension of the co-learning and training event in which the onus did not fall on any one particular person. Youth and visiting researchers co-facilitated in turn as needed, identified areas needing further elucidation, and observed and acted on research participants' verbal and non-verbal cues.

One challenge with including youth cultural liaisons as co-facilitators was that their ties to the community limited their availability. Family, school, and community events, as well as extracurricular activities and jobs resulted in a flux in youth participation. Also, since youth were Inuit or from the community, some research participants initially hesitated to answer certain questions or did not elaborate fully, knowing that youth already knew the answer (e.g., notable events in the past, cultural nuances). Youth co-facilitators needed to be aware of their own knowledge and avoid leading participants. At the same time, they tried to draw detailed perspectives from participants so that the visiting researchers could fully understand the content and context of the discussion. While co-facilitating, at times youth found it exasperating and difficult to not interject when research participants omitted to share certain knowledge that youth themselves had and felt should be documented. Youth co-facilitators, particularly those with minimal prior interactions with Elders and other well-respected and knowledgeable community members, were sometimes hesitant to ask direct questions or request additional details. Asking direct questions, especially of Elders, is generally not a cultural practice; learning happens through careful 
listening and observation, as well as through personal experience (Karetak et al., 2017; McGrath, 2018). Therefore, youth defer to Elders and do not want to interrupt them. However, through co-facilitation of workshops, youth were empowered and emboldened to ask questions because they wanted to ensure that the visiting researchers understood the nuances, context, and significance of the knowledge being shared. Elders expressed amazement and satisfaction that youth had displayed such confidence while co-facilitating the discussions.

At times, Elders shared lengthy, detailed stories about the past that seemed, to the visiting researchers, to be beyond the scope of the research topic. Like McGregor et al. (2010), we found that even when listening carefully, the meaning of Elders' stories was not always immediately clear to visiting researchers and required a nuanced interpretation from youth cultural liaisons (i.e., to clarify the linkages between Elders' stories and the research topic). Often, it took a considerable amount of time and community engagement for visiting researchers to gain the experience needed to become aware of and comprehend underlying meanings intended in Elders' stories. And even then, individual listeners will interpret Elders' meanings in a way that is unique to their personal experience and contextual understanding. However, youth and other research participants revelled in hearing these stories and did not feel they were beyond the project scope. One Cambridge Bay youth said that a positive part of the project was "hearing, learning, and listening to the Elders." Another said that "working with the Elders was great [because] we heard stories of how life was in the past."

Limits to language fluency, caused largely by the residential school system, is an area of discomfort for Inuit (Kirmayer et al., 2003). It was vital that the research team exercise a high degree of sensitivity regarding bilingualism. To increase the accuracy and comprehensiveness of communication between English-speaking visiting researchers, Inuktut-speaking Elders, and any youth who were not comfortably bilingual, skilled interpreters were hired. This had budgetary and time ramifications, but was integral to documenting Elders' knowledge. Bilingual discussions require more time than unilingual ones; and expenses (honoraria, room rental, catering, youth and interpreter wages) were dependent upon discussion duration. Not all youth were fluent in the local dialect, making them reluctant to co-facilitate and inhibiting their ability to take extensive, detailed notes.

\section{Results Validation and Sharing}

During results validation, knowledge gaps were filled and incorrect information and interpretations were corrected (Table 7). Having research participants verify analyses and confirm their authenticity served as a quality control process for qualitative research wherein researchers sought "to improve the accuracy, credibility and validity" of documented knowledge (Lincoln and Guba, 1985; Harper and Cole, 2012:1). The incidence of incorrect information or incorrect interpretation was decreased (Creswell and Miller, 2000; Pearce et al., 2009). Building on respectful practices, and to ensure that interpretations and the framing of results were in line with community intentions, the research team provided community members with research result summaries, thus minimizing the potential for misunderstanding or misuse by other audiences (Fernandez et al., 2003). Sharing and validating results also allowed consensus among participants and community organizations to be strengthened-for example, about the location of culturally significant marine areas and marine vessel management recommendations (Breton-Honeyman et al., 2016). To the extent that sharing results is a critically important, increasingly common practice and a common requirement for supporting research (ITK and NRI, 2007; Pearce et al., 2009; Castleden et al., 2012; Healey and Tagak, 2014; ITK, 2018a, b), we agree with Fernandez (2003:18) that "respect doesn't end with consent." Sharing results helped researchers avoid "treating persons solely as a means to an end" (Fernandez, 2003:12) and helped cultivate community trust in researchers.

In-person discussions after reviewing project outputs afforded participants the opportunity to modify the degree to which they wished their participation to be confidential or recognized. Co-facilitated results sharing with the broader community created opportunities for critique and augmentation of project outputs, discussions within and between local organizations and community members about the research topic, intergenerational knowledge sharing, and raising community awareness about the project. Youth further developed and gained confidence in their public speaking skills and recognition in the community as being active and skilled researchers. Several youth reported that they did not usually attend community meetings. Others said that they had never before spoken at a community meeting, but now felt they would attend more community meetings and participate. Powers and Tiffany (2006) reported similar increases in youth civic engagement as an outcome of youth involvement in research initiatives. An Elder research participant and member of a community partner organization encouraged the youth to continue their work: "...my advice on behalf of the HTO-continue the work you are doing and get lots of involvement with the community. Get involved with the HTO. The HTO plays an important part in the community. If you can [already] do what you're doing [with this project] we have a lot of opportunities for you." In Cambridge Bay, youth learned that they could approach Elders to ask them to share their knowledge. "Now you know, we don't bite and we will answer [your questions]," one Elder told them near the end of the workshop. Additional trust was fostered between visiting researchers and community members. For instance, following the workshop in Cambridge Bay, one EHTO member told the visiting researchers that if they ever needed anything from EHTO, they should not hesitate to ask. A Pond Inlet partner also reflected that not everyone who 
TABLE 7. Benefits, challenges, and lessons learned while conducting results validation and sharing during partnership research and capacity enhancement in Inuit Nunangat.

\begin{tabular}{|c|c|c|}
\hline $\begin{array}{l}\text { - Pre-validating project outputs with youth cultural } \\
\text { liaisons (YCL) increased output accuracy (draft } \\
\text { summary report and maps) and decreased } \\
\text { participant burden to make corrections. } \\
\text { - Prior trust between YCL and visiting researchers } \\
\text { made pre-validation open and frank. Errors were } \\
\text { understood to be unintentional. Information lost in } \\
\text { translation was incorporated. } \\
\text { - Project outputs were culturally appropriate and } \\
\text { written in non-technical language that accurately } \\
\text { reflected participants' views and community } \\
\text { sentiments and were relevant to local interests and } \\
\text { needs. }\end{array}$ & - YCL were sometimes unavailable to participate. & $\begin{array}{l}\text { - Determine availability and conduct pre-validation } \\
\text { at times when youth are available (e.g., evenings } \\
\text { or for multiple brief timeslots), via conference } \\
\text { calls, in-person meetings, or social media to boost } \\
\text { participation. } \\
\text { - Plan time for YCL to become familiar with draft } \\
\text { outputs prior to pre-validation. } \\
\text { - Take frequent breaks to assist with maintaining } \\
\text { focus and quality during this process. }\end{array}$ \\
\hline $\begin{array}{l}\text { - Validating project outputs with participants } \\
\text { increased output accuracy and comprehensiveness. } \\
\text { - Demonstrated research team's respect was a } \\
\text { form of reciprocity and meaningful participant } \\
\text { involvement. } \\
\text { - Fostered additional trust between the research } \\
\text { team and participants. } \\
\text { - An opportunity for VR to confirm which results } \\
\text { could be shared publicly. } \\
\text { - An opportunity for participants to modify the } \\
\text { degree to which their participation was credited or } \\
\text { confidential. }\end{array}$ & $\begin{array}{l}\text { - Some did not participate. } \\
\text { Views about remuneration differed between } \\
\text { community partners (CP), research participants, } \\
\text { and VR, which resulted in disappointment } \\
\text { and uncomfortable conversations and } \\
\text { situations. }\end{array}$ & $\begin{array}{l}\text { - Offer to share summary results with research } \\
\text { participants in group format or individually and } \\
\text { accept that some may not participate. } \\
\text { - Discuss appropriate remuneration within the } \\
\text { research team and then with participants. Some } \\
\text { CPs may be equipped to contribute financially to } \\
\text { results sharing. }\end{array}$ \\
\hline $\begin{array}{l}\text { - Sharing results with local organizations, } \\
\text { including partners, increased community } \\
\text { members' awareness of project outputs and VR } \\
\text { confidence in sharing results publicly outside the } \\
\text { community. }\end{array}$ & $\begin{array}{l}\text { - Existing workload strained CP's capacity to meet } \\
\text { for results sharing. }\end{array}$ & $\begin{array}{l}\text { - Offer to share summary, non-technical results with } \\
\text { community partners, schools, and organizations } \\
\text { (e.g., Hamlet staff, Hamlet Council, HTO). } \\
\text { - Accept that some may not wish to or be able to } \\
\text { participate. Remain flexible about time-of-day } \\
\text { and duration. Contact potential audiences well } \\
\text { in advance and ask to be included on meeting } \\
\text { agendas. } \\
\text { - Special meetings solely for results sharing have } \\
\text { budgetary ramifications (member honoraria), } \\
\text { whereas speaking at regular meetings } \\
\text { (e.g., monthly Hamlet Council meeting) do not. } \\
\text { - Provide summary outputs to local organizations } \\
\text { (hard copy and electronic; English and local } \\
\text { dialect), as well as published manuscripts. }\end{array}$ \\
\hline
\end{tabular}

comes to do research and consultations gets hugs when they are leaving, as happened during the AC-NV project.

When validating and sharing results, the challenges were similar to those described earlier relating to knowledge documentation, co-refinement of the knowledge documentation tool, and visiting researchers partnering with local organizations. The research team offered to validate results with participants and to share results in the community, and invested significant resources (e.g., funds, time, effort) in doing so. Expectations surrounding remuneration for results validation differed between the research team and participants. The research team viewed the opportunity to review draft maps and reports as giving-back to participants and thought that because project outputs would inform policies that would benefit communities, validation would be perceived by research participants as being inherently valuable. Thus, initially participant remuneration was not budgeted for or provided. At the advice of community partners, in three of the four communities, participants were given a token gift, an opportunity to win a door prize, or received no remuneration, respectively. Participation rates were low, and in one community no participants attended. Youth and participants later reported that remuneration had been expected as a way of valuing peoples' time. One research participant reflected that validation only benefits researchers, and thus did not wish to participate. So, in the last of the four communities, with new funding secured by visiting researchers and community partners, participants were remunerated for a full day. Every participant attended, and several brought their spouses to observe.

During knowledge documentation, the research team consulted participants about how and when results should be validated and shared. However, the research team did not discuss how results validation benefitted visiting researchers, participants, and communities alike and had not decided upon remuneration in advance. Had this discussion taken place, greater understanding between 
participants and the research team may have been achieved, and misunderstandings prevented. Some participants expressed their preference that results validation and sharing be an iterative process wherein participants validate draft outputs, edited outputs are shared with the broader community, then revised, and again validated by the research participants, until final outputs are agreed upon. This would have required three or more visits, or additional time spent in the community, which had time and budgetary ramifications that visiting researchers were unable to meet.

In keeping with the numerous instances in the literature of creative and diverse means of reporting to reach a broad range of community members and audiences - not merely research audiences-we employed additional means of results sharing (e.g., see Pearce at al., 2009; Laidler and Grimwood, 2010; Castleden et al., 2012). Visiting researchers e-mailed electronic versions of community reports to youth cultural liaisons and community partners and organizations. Travellers (authors and other visiting researchers, youth cultural liaisons, southern-based partners, and graduate students) delivered hard copies to community partners and organizations for dispersal and placement in key community locations (e.g., Hamlet office, Wildlife office, HTO) as opportunities arose. Visiting researchers, youth cultural liaisons, and community partners also posted links to the open access project website where digital copies of community reports were available and used community Facebook group pages to notify community members where hard copies were available locally. Visiting researchers annually e-mailed one-page project progress-and-impact updates to youth cultural liaisons and community partners and organizations. This manuscript and peer-reviewed publications in preparation will be similarly shared upon publication.

\section{Forming Personal Friendships}

Like Gearheard and Shirley (2007), Pearce et al (2009), Tondu et al. (2014), and others we reviewed, the development of personal friendships between visiting researchers and community members is highly important. Community partners reminded the visiting researchers that the stronger your relationship in the community, the more community members will care about what you do. One community partner reflected that "community members are not textbooks nor do they wish to be treated like iPods." As such, visiting researchers, community partners, youth, and community members were open to developing personal friendships and connections. Friendships arose through time spent together, when participating in research activities, at local activities such as square dancing, drum dancing, sewing, grocery shopping, volunteering at the school breakfast program, eating at the local hotel, and on-the-land experiences such as ice fishing, boating, snowmobiling, and berry picking, as well as meal-sharing, and drinking tea together. Mutual trust and respect developed, and common ground and interests were found. Results validation and sharing were happy occasions punctuated by hugs, smiles, and warm welcomes when visiting researchers and community members were reunited. Ongoing social media and in-person interactions continue to strengthen those bonds and friendships even years later. It is important to note that not all friendships were equal; usually the closest connections formed between those who worked together most closely and often (see also Castleden et al., 2012; Morris, 2016), and this is what led to co-authorship for us. We agree with Gearheard and Shirley (2007:72) that “...a willingness to contribute extra time and resources to engage in community life and collaborate with community members is a good start to gaining support and sparking local collaborations." Not only did it enrich our research and the shared research experience, it also enriched the lives of southern and northern people.

\section{CONCLUSION}

The overarching aim of the AC-NV project was to document Inuit knowledge and perspectives on marine shipping for infusion into federal-level policy-namely, the low-impact shipping corridors. However, the process of conducting this research led us to reflect on our approach and the methodology we engaged in while conducting the research. The lessons we learned in this partnered research included the importance of 1) conducting research that is relevant to local needs and interests, 2) visiting researchers and local organizations partnering together, 3) co-creating and refining knowledge documentation tools, 4) including youth cultural liaisons as co-facilitators, 5) conducting results validation and sharing exercises, and 6) being open to forming personal friendships. These efforts aimed to ensure that community members' voices were fully and accurately documented to inform the refinement of lowimpact shipping corridors, and they have been and will continue to be shared directly with policy and decision makers. Our partnered approach also directly contributed to project success and augmented the overall quality of our research in terms of depth, breadth, accuracy, comprehensiveness, and unambiguous articulation of diverse perspectives. Throughout this process we had successes, but it is also important to acknowledge that we made mistakes and experienced challenges. These challenges highlight the need for flexibility and sensitivity when conducting community-based research in Inuit Nunangat. Challenges that arise when Indigenous peoples and non-Indigenous researchers work together have been well-documented (see review in Snow, 2018). Developing collaborative research approaches between communities across Inuit Nunangat and non-Inuit researchers is integral to ensuring projects are conducted in a culturally respectful manner and contribute towards the goals of Inuit selfdetermination in research (Ferrazzi et al., 2018; ITK, 2018a). 
For Indigenous research to be successful in the contemporary context, processes must be accountable and include planning, documentation, interpretation, analyses, and validation that are rigorous, and results sharing must be conducted in ways that effectively return the research to the community (ITK and NRI, 2007; Pearce et al., 2009; McGregor et al., 2010; Healey and Tagak, 2014). Moreover, communities are strengthened through initiatives that 1) promote community engagement, cultural competency, and respect for Indigenous knowledge, 2) improve inter- and intragenerational relationships, strengthen social networks, and focus on investments in resources such as capacity development and workforce training, 3) are strongly grounded in Inuit history and culture, and 4) involve strong networks of support and strengths-based youth engagement and empowerment (Armstrong and Manion, 2013; Tighe and McKay, 2014; ITK, 2016; Mental Health Innovation Network, 2018).

Inuit Nunangat residents have articulated that the way in which research is conducted in and around their communities is as important as what is actually achieved in terms of new knowledge. That statement "rings true throughout the North" (Gearheard and Shirley 2007:72). Communities want to be heard, to be actively involved, and to be taken seriously. Communities want research to be relevant and reflect local priorities. Communities want to be part of research projects and to be fully engaged rather than just having information extracted and then fed back to them. "Working with local organizations and community members in a joint intellectual effort to realize shared goals generates research that will have a greater application and relevance to the community" (Tondu et al., 2014:422).

In Canada, the emerging Indigenous research paradigm calls for research that is conducted by and with (versus on) Indigenous people (McGregor et al., 2010; ITK, 2018a; Pfeifer, 2018). We offer our lessons learned in order to contribute to ongoing discussions surrounding partnership research, capacity enhancement, and Inuit self-determination, and to support future efforts in this emerging partnership approach to research (McGregor et al., 2010; Brunet et al., 2014; ITK, 2018a). We hope that our reflections will be helpful for communities and visiting researchers alike and can inform future research initiatives. These suggestions are far from exhaustive and may not be applicable in all research projects or communities. Our hope is to continue an important conversation about selfdetermination in research, science sovereignty, and the importance of partnerships and capacity enhancement in research.

\section{ACKNOWLEDGEMENTS}

This work is the result of the Arctic Corridors and Northern Voices project supported by the Marine Environment Observation Prediction and Response Network (MEOPAR), Irving Shipbuilding Inc., Fisheries and Oceans Canada, Indigenous and
Northern Affairs Canada via the Nunavut General Monitoring Plan, the Pew Charitable Trusts, Michaëlle Jean Centre for Global and Community Engagement, Oceans North, Polar Knowledge Canada, Social Sciences and Humanities Research Council of Canada, and World Wildlife Fund-Canada. We are grateful to the research participants in all of the communities we worked in, and we are specifically thankful for the youth cultural liaison co-facilitators of Arviat, Cambridge Bay, Gjoa Haven, and Pond Inlet for their support and participation. We further thank Emily Angulalik, Malachi Arreak, Joe Karetak, Abraham Kublu, Simon Okpakok, Angelina Suluk, and Bobby Suluk (interpreting/translating) and to Arviat HTO, Hamlet of Arviat, Arviat Wellness Center, Haqihaqtiit Society, Aqqiumavvik Society, Ekaluktutiak HTO, Municipality of Cambridge Bay, Gjoa Haven HTO, Hamlet of Gjoa Haven, Betty Kogvik, Sammy Kogvik, Hamlet of Pond Inlet, Ikaarvik Barriers to Bridges Program, Mittimatalik HTO, Parks Canada Agency (Sirmilik National Park), the University of Ottawa Geographic, Statistical and Government Information Centre, Canadian Coast Guard, Transport Canada, Canadian Hydrographic Service, Canadian Ice Service, Julia Cary, Luke Copland, Jamie D'Souza, Holly Gordon, Megan Ihrig, Jenna Joyce, Jennie Knopp, Zuzanna Kochanowicz, Nathalie Maras, Olivia Mussells, Annika Ogilvie, Colleen Turlo, Colleen Parker, Mirya Reid, SmartICE, and Melissa Weber for project support. This project was approved by the Nunavut Research Institute (license 02004 17R-M), the Aurora Research Institute (license 16079), and the University of Ottawa Research Ethics Board (certificate 02-16-03).

\section{REFERENCES}

Advisory Panel on Federal Support for Fundamental Science. 2017. Investing in Canada's Future: Strengthening the foundations of Canadian research.

http://www.sciencereview.ca/eic/site/059.nsf/vwapj/ ScienceReview_April2017-rv.pdf/\$file/ScienceReview_ April2017-rv.pdf

Aporta, C. 2009. The trail as home: Inuit and their pan-Arctic network of routes. Human Ecology 37(2):131 - 146.

https://doi.org/10.1007/s10745-009-9213-x

Armstrong, L.L., and Manion, I.G. 2013. Meaningful youth engagement as a protective factor for youth suicidal ideation. Journal of Research on Adolescence 25(1):20-27. https://doi.org/10.1111/jora.12098

Barnaby, J., Legat, A., Price, J., and Labba, N. 2009. Indigenous decision making processes: What can we learn from traditional governance? The Arctic Governance Project.

https://arcticgovernance.custompublish.com/indigenousdecision-making-processes-what-can-we-learn-fromtraditional-governance.4667318-142902.html

Beaumier, M.C., Ford, J.D., and Tagalik, S. 2015. The food security of Inuit women in Arviat, Nunavut: The role of socio-economic factors and climate change. Polar Record 51(5):550-559.

https://oi.org/10.1017/S0032247414000618 
Bell, T., Briggs, R., Bachmayer, R., and Li, S. 2014. Augmenting Inuit knowledge for safe sea-ice travel: The SmartIce information system. 2014 Oceans-St. John's, St. John's, NL. $1-9$. https://doi.org/10.1109/OCEANS.2014.7003290

Bennett, J., and Rowley, S., eds. 2004. Uqalurait: An oral history of Nunavut. Montreal, Quebec: McGill-Queen's University Press.

Bonny, E., and Berkes, F. 2008. Communicating traditional environmental knowledge: Addressing the diversity of knowledge, audiences and media types. Polar Record 44(3):243-253. https://doi.org/10.1017/S0032247408007420

Breton-Honeyman, K., Hammill, M.O., Furgal, C.M., and Hickie, B. 2016. Inuit knowledge of beluga whale (Delphinapterus leucas) foraging ecology in Nunavik (Arctic Quebec), Canada. Canadian Journal of Zoology 94(10):713-726.

https://doi.org/10.1139/cjz-2015-0259

Brunet, N.D., Hickey, G.M., and Humphries, M.M. 2014. The evolution of local participation and the mode of knowledge production in Arctic research. Ecology and Society 19(2): 69. https://doi.org/10.5751/ES-06641-190269

___ 2016. Local participation and partnership development in Canada's Arctic research: Challenges and opportunities in an age of empowerment and self-determination. Polar Record 52(3):345-359. https://doi.org/10.1017/S003224741500090X

Butler, M.J.A., LeBlanc, C., Belbin, J.A., and MacNeill, J.L. 1987. Marine resource mapping: An introductory manual. FAO Fisheries Technical Paper 274. http://www.fao.org/3/T0390E/T0390E00.htm\#toc

Carter, N.A., Dawson, J., Joyce, J., and Ogilvie, A. 2017a. Arctic corridors and northern voices: Governing marine transportation in the Canadian Arctic (Arviat, Nunavut community report). Ottawa: University of Ottawa. https://doi.org/10.20381/RUOR36924

___ 2017b. Arctic corridors and northern voices: Governing marine transportation in the Canadian Arctic (Gjoa Haven, Nunavut community report). Ottawa: University of Ottawa. https://doi.org/10.20381/RUOR36911

Carter, N.A., Dawson, J., Joyce, J., Ogilvie, A., and Weber, M. 2018a. Arctic corridors and northern voices: Governing marine transportation in the Canadian Arctic (Pond Inlet, Nunavut community report). Ottawa: University of Ottawa. https://doi.org/10.20381/RUOR37271

Carter, N., Dawson, J., Knopp, J., Joyce, J., Weber, M., Kochanowicz, Z., and Mussells, O. 2018b. Arctic corridors and northern voices: Governing marine transportation in the Canadian Arctic (Cambridge Bay, Nunavut community report). Ottawa: University of Ottawa. https://doi.org/10.20381/RUOR37325

Castleden, H., Garvin, T., and Huu-ay-aht First Nation. 2008. Modifying photovoice for community-based participatory Indigenous research. Social Science and Medicine 66(6):1393-1405.

https://doi.org/10.1016/j.socscimed.2007.11.030
Castleden, H., Sloan Morgan, V., and Lamb, C. 2012. "I spent the year drinking tea": Exploring Canadian university researchers' perspectives on community-based participatory research involving Indigenous peoples. The Canadian Geographer 56(2):160- 179 .

https://doi.org/10.1111/j.1541-0064.2012.00432.x

Chénier R., Abado, L., Sabourin, O., and Tardif, L. 2017. Northern marine transportation corridors: Creation and analysis of northern marine traffic routes in Canadian waters. Transactions in GIS 21(6):1085-1097.

https://doi.org/10.1111/tgis.12295

Christopher, S., Watts, V., McCormick, A.K.H.G., and Young, S. 2008. Building and maintaining trust in a community-based participatory research partnership. American Journal of Public Health 98(8):1398-1406.

https://doi.org/10.2105/AJPH.2007.125757

Clark, T. 2008. "We're over-researched here!” Exploring accounts of research fatigue within qualitative research engagements. Sociology 42(5):953-970. https://doi.org/10.1177/0038038508094573

Creswell, J.W., and Miller, D.L. 2000. Determining validity in qualitative inquiry. Theory into Practice 39(3):124-130.

https://doi.org/10.1207/s15430421tip3903_2

Cunsolo, A., and Hudson, A. 2018. Relationships, resistance, and resurgence in northern-led research. Northern Public Affairs. $23-28$.

http://www.northernpublicaffairs.ca/index/relationshipsresistance-resurgence-in-northern-led-research/

Cunsolo Willox, A., Harper, S.L., Ford, J.D., Landman, K., Houle, K., Edge, V.L., and the Rigolet Inuit Community Government. 2012. "From this place and of this place:" Climate change, sense of place, and health in Nunatsiavut, Canada. Social Science and Medicine 75(3):538-547.

https://doi.org/10.1016/j.socscimed.2012.03.043

Dawson, J., Porta, L., Okuribido-Malcolm, S., deHann, M., and Mussells, O. 2016. Proceedings of the Northern Marine Transportation Corridors Workshop, 8 December 2015, Vancouver, British Columbia. Ottawa: uO Research.

http://www.espg.ca/wp-content/uploads/2013/04/NMTC_ Workshop_Proceedings_FINAL_REVISED.pdf

Dawson, J., Mussells, O., Copland, L., and Carter, N. 2017. Shipping trends in Nunavut from 1990-2015: A report prepared for the Nunavut General Monitoring Program. Ottawa, Ontario and Iqaluit, Nunavut.

http://www.arcticcorridors.ca/wp-content/uploads/2017/11/ NGMP-Shipping-Report_2017-V1.pdf

Dawson, J., Pizzolato, L., Howell, S.E.L., Copland, L., and Johnston, M.E. 2018. Temporal and spatial patterns of ship traffic in the Canadian Arctic from 1990 to 2015. Arctic 71(1): $15-26$.

https://doi.org/10.14430/arctic4698

Dawson, J., Carter, N., van Luijk, N., Parker, C., Weber, M., Greydanus, K., and Provencher, J. In press. Infusing local knowledge and community perspectives into the low impact shipping corridors: An adaptation to increased shipping activity and climate change in Arctic Canada. Environmental Science and Policy. 
Department of Justice Canada. 2018. Principles respecting the Government of Canada's relationship with Indigenous peoples. https://www.justice.gc.ca/eng/csj-sjc/principles-principes.html

DFO (Fisheries and Oceans Canada). 2011. Identification of ecologically and biologically significant areas (EBSA) in the Canadian Arctic. Canadian Science Advisory Secretariat, Science Advisory Report 2011/055. http://waves-vagues.dfo-mpo.gc.ca/Library/344747.pdf

Durkalec, A., Furgal, C., Skinner, M.W., and Sheldon, T. 2015. Climate change influences on environment as a determinant of Indigenous health: Relationships to place, sea ice, and health in an Inuit community. Social Science and Medicine 136-137:17-26. https://doi.org/10.1016/j.socscimed.2015.04.026

ESPG (Environment, Society and Policy Group). 2019. Arctic corridors research for policy on shipping governance in Arctic Canada. Ottawa: ESPG, University of Ottawa. http://www.arcticcorridors.ca

Fernandez, C.V., Kodish, E., and Weijer, C. 2003. Informing study participants of research results: An ethical imperative. IRB: Ethics \& Human Research 25(3):12-19. https://doi.org/10.2307/3564300

Ferrazzi, P., Christie, P., Jalovcic, D., Tagalik, S., and Grogan, A. 2018. Reciprocal Inuit and Western research training: Facilitating research capacity and community agency in Arctic research partnerships. International Journal of Circumpolar Health 77(1): Article 1425581.

https://doi.org/10.1080/22423982.2018.1425581

Gearheard, S., and Shirley, J. 2007. Challenges in communityresearch relationships: Learning from natural science in Nunavut. Arctic 60(1):62-74. https://doi.org/10.14430/arctic266

Gearheard, S.F., Kielsen Holm, L., Huntington, H., Leavitt, J.M., Mahoney, A.R., Opie, M., Oshima, T., and Sanguya, J., eds. 2013. The meaning of ice: People and sea ice in three Arctic communities. Hanover, New Hampshire: International Polar Institute Press.

Government of Nunavut (GN). 2010. Elders program strategy 2010-2014. Department of Culture, Language, Elders and Youth.

https://gov.nu.ca/sites/default/files/2010-2014-elders_strategy. pdf

Government of Canada. 2011. Aboriginal consultation and accommodation: Updated guidelines for federal officials to fulfill the duty to consult.

https://www.aadnc-aandc.gc.ca/DAM/DAM-INTER-HQ/ STAGING/texte-text/intgui_1100100014665_eng.pdf

2012. Nunavut infrastructure: Building our infrastructure.

Department of Executive and Intergovernmental Affairs. https://www.gov.nu.ca/eia/documents/nunavut-infrastructure

Grimwood, B.S.R., Doubleday, N.C., Ljubicic, G.J., Donaldson, S.G., and Blangy, S. 2012. Engaged acclimatization: Towards responsible community-based participatory research in Nunavut. The Canadian Geographer 56(2):211-230. https://doi.org/10.1111/j.1541-0064.2012.00416.x
Harper, M., and Cole, P. 2012. Member checking: Can benefits be gained similar to group therapy? The Qualitative Report $17(2): 1-8$.

https://nsuworks.nova.edu/tqr/vol17/iss2/1/

Harper, S.L., Edge, V.L., Ford, J., Cunsolo Willox, A., Wood, M., IHACC Research Group, Rigolet Inuit Community Government, and McEwen, S.A. 2015. Climate-sensitive health priorities in Nunatsiavut, Canada. BMC Public Health 15: Article 605.

https://doi.org/10.1186/s12889-015-1874-3

Healey, G., and Tagak, A., Sr. 2014. Piliriqatigiinniq "Working in a collaborative way for the common good": A perspective on the space where health research methodology and Inuit epistemology come together. International Journal of Critical Indigenous Studies 7(1):1-14.

Henri, D.A., Jean-Gagnon, F., and Gilchrist, H.G. 2018. Using Inuit traditional ecological knowledge for detecting and monitoring avian cholera among Common Eiders in the eastern Canadian Arctic. Ecology and Society 23(1): 22. https://doi.org/10.5751/ES-09289-230122

Ikaarvik. 2015. Ikaarvik works with youth to build connections between scientists and Inuit communities. Vancouver, British Columbia: Ocean Wise Research. https://research.ocean.org/project/ikaarvik

IFAD (International Fund for Agricultural Development). 2009. Good practices in participatory mapping. http://www.iapad.org/wp-content/uploads/2015/07/ifad_ good_practice_in-participatory_mapping.pdf

ICC (Inuit Circumpolar Council) Canada. 2008. The sea ice is our highway: An Inuit perspective on transportation in the Arctic. A contribution to the Arctic Marine Shipping Assessment. http://awsassets.panda.org/downloads/sea_ice_highway.pdf

__ 2013. Circumpolar Inuit Response to Arctic Shipping Workshop proceedings, 14-15 March 2013, Ottawa, Canada. https://secureservercdn.net/104.238.71.250/hh3.0e7. myftpupload.com/wp-content/uploads/2019/01/201309121300 arcticshippingscreenversion_revised.pdf

ITK (Inuit Tapiriit Kanatami). 2016. National Inuit suicide prevention strategy. Ottawa: ITK.

https://www.itk.ca/wp-content/uploads/2016/07/ITKNational-Inuit-Suicide-Prevention-Strategy-2016.pdf

___ 2018a. National Inuit strategy on research. Ottawa: ITK. https://www.itk.ca/wp-content/uploads/2018/04/ITK_NISRReport_English_low_res.pdf

__ 2 2018b. National Inuit strategy on research: Implementation plan. Ottawa: ITK. https:/www.itk.ca/wp-content/uploads/2018/09/ITK_NISR_ Implementation-Plan_Electronic-Version.pdf

ITK and NRI (Inuit Tapiriit Kanatami and Nunavut Research Institute). 2007. Negotiating research relationships with Inuit communities: A guide for researchers. Nickels, S., Shirley, J., and Laidler, G., eds. Ottawa: ITK; Iqaluit: NRI. 38 p.

Karetak, J., Tester, F., and Tagalik, S., eds. 2017. Inuit Qaujimajatuqangit: What Inuit have always known to be true. Winnipeg, Manitoba: Fernwood Publishing. 
Kendrick, A., and Manseau, M. 2008. Representing traditional knowledge: Resource management and Inuit knowledge of barren-ground caribou. Society and Natural Resources: An International Journal 21(5):404-418. https://doi.org/10.1080/08941920801898341

Kirmayer, L., Simpson, C., and Cargo, M. 2003. Healing traditions: Culture, community and mental health promotion with Canadian Aboriginal peoples. Australasian Psychiatry 11(s1):S15-S23. https://doi.org/10.1046/j.1038-5282.2003.02010.x

Krupnik, I., Aporta, C., Gearheard, S., Laidler, G.J., and Kielsen Holm, L., eds. 2010. SIKU: Knowing our ice: Documenting Inuit sea-ice knowledge and use. Dordrecht: Springer.

Laidler, G.J. 2006. Some Inuit perspectives on working with scientists. Meridian Spring/Summer:4-10.

Laidler, G.J., Ford, J.D., Gough, W.A., Ikummaq, T., Gagnon, A.S., Kowal, S., Qrunnut, K., and Irngaut, C. 2009. Travelling and hunting in a changing Arctic: Assessing Inuit vulnerability to sea ice change in Igoolik, Nunavut. Climatic Change 94(3-4):363-397. https://doi.org/10.1007/s10584-008-9512-z

Lee, D.S., and Wenzel, G.W. 2004. Narwhal hunting by Pond Inlet Inuit: An analysis of foraging mode in the floe-edge environment. Études Inuit Studies 28(2):133-157.

Lincoln, Y.S., and Guba, E.G. 1985. Naturalistic inquiry. Newbury Park, California: Sage Publications.

Ljubicic, G., Okpakok, S., Robertson, S., and Mearns, R. 2018. Uqsuqtuurmiut inuita tuktumi qaujimaningit (Inuit knowledge of caribou from Gjoa Haven, Nunavut): Collaborative research contributions to co-management efforts. Polar Record 54(3):213-233. https://doi.org/10.1017/S0032247418000372

Loseto, L.L., Brewster, J.D., Ostertag, S.K., Snow, K., MacPhee, S.A., McNicholl, D.G., Choy, E.S., Giraldo, G., and Hornby, C.A. 2018. Diet and feeding observations from an unusual beluga harvest in 2014 near Ulukhaktok, Northwest Territories, Canada. Arctic Science 4(3):421 - 431. https://doi.org/10.1139/as-2017-0046

MacDonald, J., and Wachowich, N., eds. 2018. The hands' measure: Essays honouring Leah Aksaajuq Otak's contributions to Arctic science. Iqaluit: Nunavut Arctic College Media.

McGrath, J.T. 2019. The Qaggiq model: Toward a theory of Inuktut knowledge renewal. Iqaluit: Nunavut Arctic College Media.

McGregor, D., Bayha, W., and Simmons, D. 2010. "Our responsibility to keep the land alive": Voices of northern Indigenous researchers. Pimatisiwin: A Journal of Aboriginal and Indigenous Community Health 8(1):101-123.

Mental Health Innovation Network. 2018. The RISING SUN toolkit for resilience..

https://www.mhinnovation.net/collaborations/rising-sun/ rising-sun-toolkit

Morris, M. 2016. Inuit involvement in developing a participatory action research project on youth, violence prevention, and health promotion. Études Inuit Studies 40(1):105-125.

https://doi.org/10.7202/1040147ar
Nadalin, V., Maar, M., Ashbury, F., and McLaughlin, J. 2013. Issues in the recruitment and retention of Aboriginal health research participants in Canada. In: White, J.P., Peters, J., Dinsdale, P., and Beavon, D., eds. Aboriginal policy research Vol. 9: Health and well-being. Toronto, Ontario: Thompson Educational Publishing, Inc. 143-160.

NGPRC (Northern Governance Policy Research Conference). 2009. NGPRC draft recommendations. Recommendations from the NGPRC, 3-5 November 2009, Yellowknife, Northwest Territories.

Nowell, L.S., Norris, J.M., White, D.E., and Moules, N.J. 2017. Thematic analysis: Striving to meet the trustworthiness criteria. International Journal of Qualitative Methods 16(1). https://doi.org/10.1177/1609406917733847

Ogden, A., and Thomas, M.-E. 2013. Letter to the Editor re: The Lakehead Manifesto. Arctic 66(4):508.

https://doi.org/10.14430/arctic4342

OPM (Office of the Prime Minister). 2016a. United States-Canada joint Arctic leader's statement.

https://pm.gc.ca/eng/news/2016/12/20/united-states-canadajoint-arctic-leaders-statement

___ 2016b. Canada's Oceans Protection Plan: Creating stronger Indigenous partnerships and engaging coastal communities.

https://pm.gc.ca/eng/news/2016/11/07/canadas-oceansprotection-plan-creating-stronger-indigenous-partnershipsand

- 2016c. The Prime Minister of Canada announces the national Oceans Protection Plan.

https://pm.gc.ca/eng/news/2016/11/07/prime-minister-canadaannounces-national-oceans-protection-plan

___ 2018. Government of Canada to create recognition and implementation of rights framework.

https://pm.gc.ca/eng/news/2018/02/14/government-canadacreate-recognition-and-implementation-rights-framework

Pearce, T.D., Ford, J.D., Laidler, G.J., Smit, B., Duerden, F., Allarut, M., Andrachuk, M., et al. 2009. Community collaboration and climate change research in the Canadian Arctic. Polar Research 28(1):10-27.

https://doi.org/10.1111/j.1751-8369.2008.00094.x

Pearce, T., Ford, J., Cunsolo Willox, A., and Smit, B. 2015. Inuit traditional ecological knowledge (TEK) subsistence hunting and adaptation to climate change in the Canadian Arctic. Arctic 68(2):233-245.

https://doi.org/10.14430/arctic4475

Pew Charitable Trusts. 2016. The integrated Arctic corridors framework: Planning for responsible shipping in Canada's Arctic waters. Washington, D.C.: The Pew Charitable Trusts. https://www.pewtrusts.org/ /media/assets/2016/04/theintegrated-arctic-corridors-framework.pdf

Pfeifer, P. 2018. From the credibility gap to capacity building: An Inuit critique of Canadian Arctic Research. Northern Public Affairs.

http://www.northernpublicaffairs.ca/index/volume-6-issue-1/ from-the-credibility-gap-to-capacity-building-an-inuitcritique-of-canadian-arctic-research/ 
Pizzolato, L., Howell, S.E.L., Derksen, C., Dawson, J., and Copland, L. 2014. Changing sea ice conditions and marine transportation activity in Canadian Arctic waters between 1990 and 2012. Climatic Change 123(2):161-173.

https://doi.org/10.1007/s10584-013-1038-3

Pizzolato, L., Howell, S.E.L., Dawson, J., Laliberté, F., and Copland, L. 2016. The influence of declining sea ice on shipping activity in the Canadian Arctic. Geophysical Research Letters 43(23):12146-12154. https://doi.org/10.1002/2016GL071489

Powers, J.L., and Tiffany, J.S. 2006. Engaging youth in participatory research and evaluation. Journal of Public Health Management Practice November Suppl.:S79-S87.

https://www.health.ny.gov/community/youth/development/ docs/jphmp_s079-s087.pdf

Preston, J.P., Claypool, T.R., Rowluck, W., and Green, B. 2015. Exploring the concepts of traditional Inuit leadership and effective school leadership in Nunavut (Canada). Comparative and International Education 44(2): Article 2.

Prestwich, E. 2014. Young Hunters program in Arviat, Nunavut teaches kids skills they've never learned. The Huffington Post Canada.

https://www.huffingtonpost.ca/2014/09/02/young-huntersnunavut_n_5652698.html

Qitsualik, R.A. 1999. Living with change. In: Nunavut '99: Changing the map of Canada.

http://www.nunavut.com/nunavut99/english/change.html

Rogers, S. 2014. Arviat group get their hands dirty in the name of food security. Nunatsiaq News, July 24.

http://nunatsiaq.com/stories/article/65674arviat_group_get their_hands_dirty_in_the_name_of_food_security/

Shlag, M., and Fast, H. 2005. Marine stewardship and Canada's Oceans Agenda in the western Canadian Arctic: A role for youth. In: Berkes, F., Huebert, R., Fast, H., Manseau, M., and Diduck, A., eds. Breaking ice: Renewable resource and ocean management in the Canadian North. Calgary: University of Calgary Press and Arctic Institute of North America. 119-140.

Simon, K.M., James, T.S., Forbes, D.L., Telka, A.M., Dyke, A.S., and Henton, J.A. 2014. A relative sea-level history for Arviat, Nunavut, and implications for Laurentide Ice Sheet thickness west of Hudson Bay. Quaternary Research 82(1):185-197. https://doi.org/10.1016/j.yqres.2014.04.002

Snow, K. 2018. What does being a settler ally in research mean? A graduate student's experience learning from and working within Indigenous research paradigms. International Journal of Qualitative Methods 17(1):1 - 11. https://doi.org/10.1177/1609406918770485

Statistics Canada. 2016. Census Profile, 2016 Census. Nunavut (Territory) and Canada (Country).

Stewart, E.J., Dawson, J., and Draper, D. 2011. Cruise tourism and residents in Arctic Canada: Development of a resident attitude typology. Journal of Hospitality and Tourism Management 18(1):95-106.

https://doi.org/10.1375/jhtm.18.1.95
Tighe, J., and McKay, K. 2014. Alive and kicking goals!: Preliminary findings from a Kimberley suicide prevention program. Advances in Mental Health 10(3):240-245. https://doi.org/10.5172/jamh.2012.10.3.240

Tobias, T.N. 2009. Living proof: The essential data-collection guide for Indigenous use-and-occupancy map surveys. Vancouver, British Columbia: Ecotrust Canada.

Tomaselli, M., Gerlach, S.C., Kutz, S.J., Checkley, S.L., and the Community of Iqaluktutiaq. 2018. Iqaluktutiaq voices: Local perspectives about the importance of muskoxen, contemporary and traditional use and practices. Arctic 71(1):1-14. https://doi.org/10.14430/arctic4697

Tondu, J.M.E., Balasubramaniam, A.M., Chavarie, L., Gantner, N., Knopp, J.A., Provencher, J.F., Wong, P.B.Y., and Simmons, D. 2014. Working with northern communities to build collaborative research partnerships: Perspectives from early career researchers. Arctic 67(3):419-429.

https://doi.org/10.14430/arctic4416

Travel Nunavut. n.d.a. Cambridge Bay. Iqaluit: Travel Nunavut Industry Association.

https://www.nunavuttourism.com/regions-of-nunavut/ communities/cambridge-bay/

___ n.d.b. Gjoa Haven. Iqaluit: Travel Nunavut Industry Association.

https://www.nunavuttourism.com/regions-of-nunavut/ communities/gjoa-haven/

__ n.d.c. Pond Inlet. Canadian Northern Economic Development Agency.

https://www.nunavuttourism.com/regions-of-nunavut/ communities/pond-inlet/

TRCC (Truth and Reconciliation Commission of Canada). 2015. Canada's residential schools: The Inuit and Northern experience final report. The Final Report of the Truth and Reconciliation Commission of Canada, Volume 2. Montreal: McGill-Queen's University Press.

http://nctr.ca/assets/reports/FinalReports/Volume_2_Inuit_ and_Northern_English_Web.pdf

Tyrrell, M. 2007. Sentient beings and wildlife resources: Inuit, beluga whales and management regimes in the Canadian Arctic. Human Ecology 35(5):575-586. https://doi.org/10.1007/s10745-006-9105-2

Wang, W.-L., Lee, H.-L., and Fetzer, S.J. 2006. Challenges and strategies of instrument translation. Western Journal of Nursing Research 28(3):310-321. https://doi.org/10.1177\%2F0193945905284712

Wesche, S.D., O'Hare-Gordon, M.A.F., Robidoux, M.A., and Mason, C.W. 2016. Land-based programs in the Northwest Territories: Building Indigenous food security and well-being from the ground up. Canadian Food Studies 3(2):23-48.

Yu, D.S.F., Lee, D.T., and Woo, J. 2004. Issues and challenges of instrument translation. Western Journal of Nursing Research 26(3):307-320.

https://doi.org/10.1177\%2F0193945903260554 